\title{
PENGGUNAAN TEORI PENGEMBANGAN RONGGA DALAM UJI MENARD PRESSUREMETER
}

\author{
Ibrahim Surya \\ Dosen Jurusan Teknik Sipil, Fakultas Teknik, Universitas Kristen Maranatha \\ E-mail: surya.ibrahim@gmail.com
}

\begin{abstract}
ABSTRAK
Uji pressuremeter telah lama dikenal mempunyai kondisi batas yang telah terdefinisikan dengan baik, karenanya analisa teoritis yang lebih akurat seperti analisa yang berdasarkan pengembangan rongga berbentuk silinder sangat cocok dipergunakan bila dibandingkan dengan percobaan insitu lainnya. Di dalam tulisan ini diberikan beberapa solusi analitis yang dikembangkan berdasarkan model konstitutif dengan berbagai tingkat kesulitan yang bertujuan memberikan pengertian dasar tentang kerangka matematis dari teori pengembangan rongga, yang dicapai dengan jalan menjelaskan solusi dari pengembangan rongga berbentuk silinder dengan anggapan perubahan bentuk yang terjadi adalah kecil (small strains).

Kata kunci: Pressuremeter, small strains, rongga.
\end{abstract}

\section{Pendahuluan}

Uji pressuremeter terdiri atas probe silinder panjang yang dikembangkan secara radial di dalam tanah sekelilingnya, dengan menggunakan sejumlah cairan bertekanan pada waktu pemompaan probe. Data dapat diinterpretasi sebagai kurva hubungan tegangan-regangan kekuatan secara lengkap. Di dalam tanah media cairan biasanya air (atau gas), sedangkan dalam batuan lapuk dan retak digunakan minyak hidraulik.

Alat pressuremeter asli diperkenalkan oleh seorang ahli Perancis Louis Menard pada tahun 1955. Prototip ini mempunyai pengaturan yang komplek dari tabung air dan udara, serta pemasangan alat ukur tekanan dan katup-katup pengujian. Pada saat ini, desain sel tunggal menggambarkan penggunaan sederhana air bertekanan dengan pompa ulir. Ringkasan prosedur dan kalibrasi diuraikan dalam ASTM D 4719 dan Gambar 1. Probe standar mempunyai diameter berkisar antara $35-73 \mathrm{~mm}$ dengan rasio panjang dan diameter $\mathrm{L} / \mathrm{d}$ bervariasi sekitar 4 - 6 yang bergantung pada pabrik pembuat.

\section{Teori pengembangan rongga (cavity expansion theory)}

Teori pengembangan rongga adalah teori tentang tegangan dan peralihan yang disebabkan oleh pengembangan dan penyusutan rongga berbentuk silinder atau bola yang tertanam dalam media yang linier atau nonlinier. Prosedur yang digunakan dalam teori pengembangan rongga untuk memecahkan permasalahan material disebut metode pengembangan rongga. Dalam beberapa puluh tahun belakangan ini, teori pengembangan 
rongga banyak dipergunakan dalam analisa dan desain didalam berbagai permasalahan dalam bidang geoteknik, karena memberikan pendekatan geomekanik yang akurat dalam studi mengenai persoalan-persoalan dalam bidang geoteknik. Diantaranya adalah kapasitas pondasi dalam dalam arah vertikal maupun lateral, interpretasi uji pressuremeter dan uji penetrasi konus dalam penentuan keadaan tanah dan parameter kuat geser tanah di lapangan dan analisa kestabilan dan peralihan yang berkaitan dengan penggalian tanah dan pembuatan terowongan.

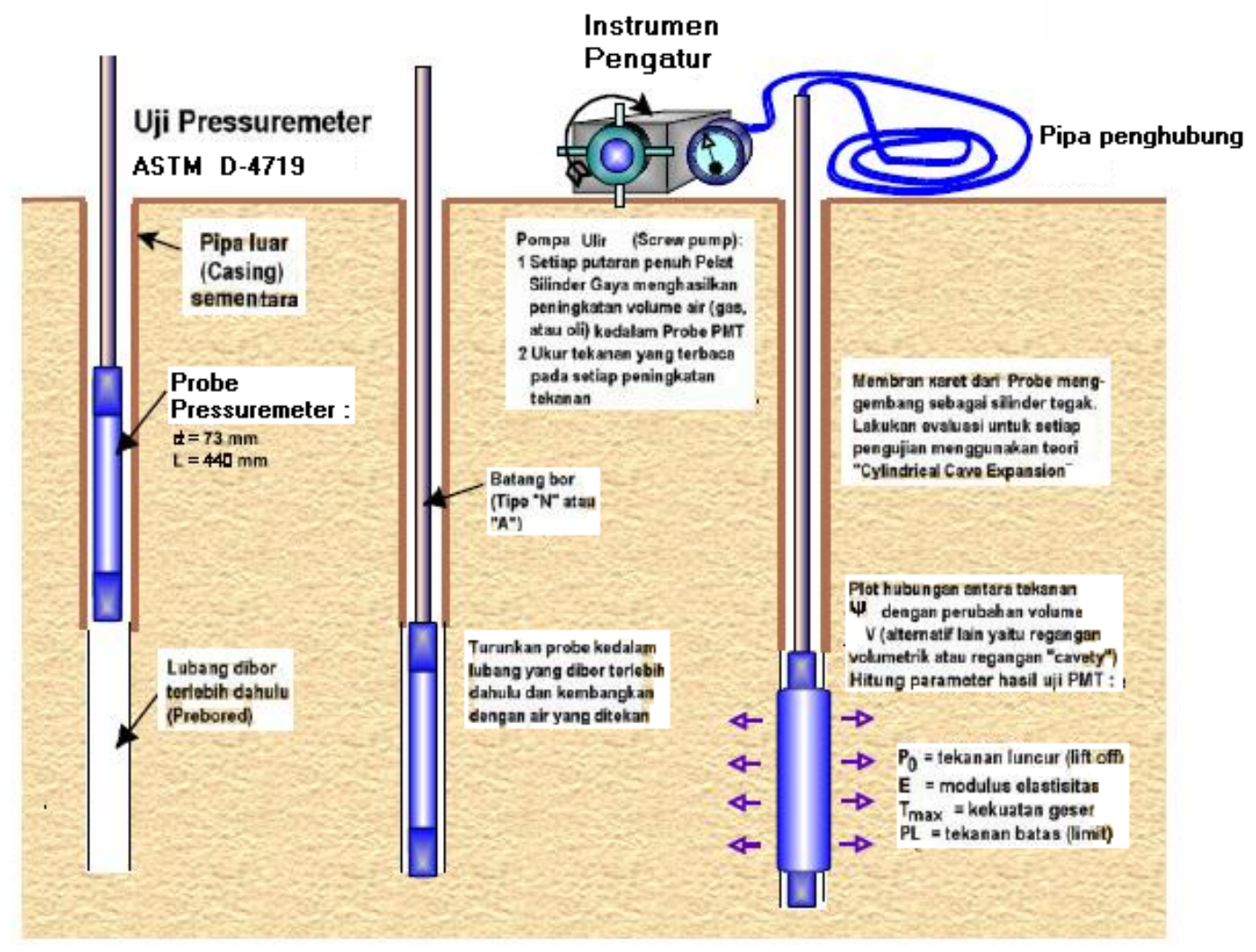

Gambar 1. Skema prosedur uji pressuremeter tipe prapengeboran (FHWA NHI-01-031).

Sampai sekarang berbagai solusi analitis telah dikembangkan untuk pengembangan rongga di dalam tanah dan batuan berdasarkan model konstitutif dengan berbagai kompleksitas.

Untuk pemecahannya digunakan prinsip mekanika kontinum, sebuah model konstitutif matematis diperlukan untuk menjelaskan perilaku tegangan-regangan dari tanah dan batuan. Teori yang banyak digunakan dalam pengembangan model tanah dan batuan adalah anggapan elastisitas dan plastisitas. Kebanyakan model tanah dan batuan dapat dibagi tiga kelompok: 
1. Model elastis (linier atau non linier)

2. Viscoelastis atau model viscoelastis-plastis

3. Model elastis-plastis (perfectly plastic atau strain hardening/softening)

Di dalam Gambar 2 di bawah ini diperlihatkan secara skematis ilustrasi penggunaan teori pengembangan rongga dalam bidang geoteknik, gambar 2 (a) mengilustrasikan uji penetrasi konus, gambar 2 (b) mengilustrasikan pondasi tiang dan gambar 2 (c) mengilustrasikan tegangan yang bekerja pada sebuah terowongan.

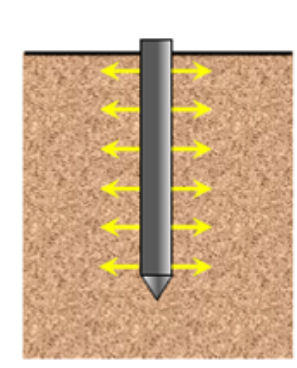

(a)

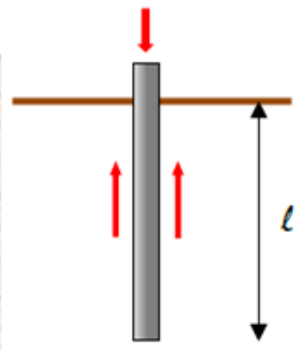

(b)

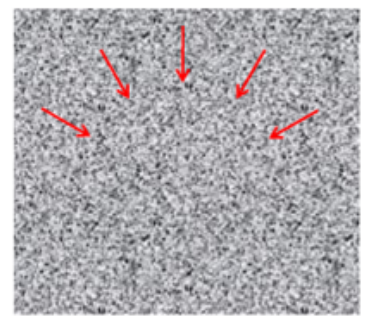

(c)

\section{Gambar 2. Ilustrasi skematis beberapa penggunaan teori pengembangan rongga [Jeremic, 2008].}

Solusi dari persoalan pengembangan rongga berbentuk silinder berdasarkan anggapan bahwa masa tanah adalah homogen, isotropis dan merupakan medium yang menerus. Karena pressuremeter secara ideal berbentuk silinder dengan panjang tak berhingga, prinsip aksial simetri (axisymmetry) dapat diterapkan dan semua pergerakannya adalah dalam arah radial. Untuk jelasnya dapat dilihat persoalan sebenarnya dan dengan prinsip axisymmetry pada Gambar 3 di bawah ini. Dalam analisa, tegangan kompresi (tekan) dan perubahan bentuknya (strain) dianggap positip sebagaimana biasanya dalam mekanika tanah.

Pendekatan dalam penyelesaian menggunakan koordinat silinder sehingga tegangan dalam keadaan keseimbangan dalam material isotropis adalah $\sigma_{r}=\sigma_{\theta}=\sigma_{z}$, dimana $\sigma_{r} \& \sigma_{\theta}$ adalah tegangan normal yang bekerja dalam arah radial dan tangensial dan $\sigma_{z}$ adalah tegangan vertikal.

Dalam medium elastis, penyelesaian persoalan rongga berbentuk silinder telah banyak dibahas misalnya dalam (Timoshenko \& Goodier, 1951) dengan persamaan : 


$$
\frac{d \sigma_{r}}{d r}=-\frac{\sigma_{r}-\sigma_{\theta}}{r}
$$

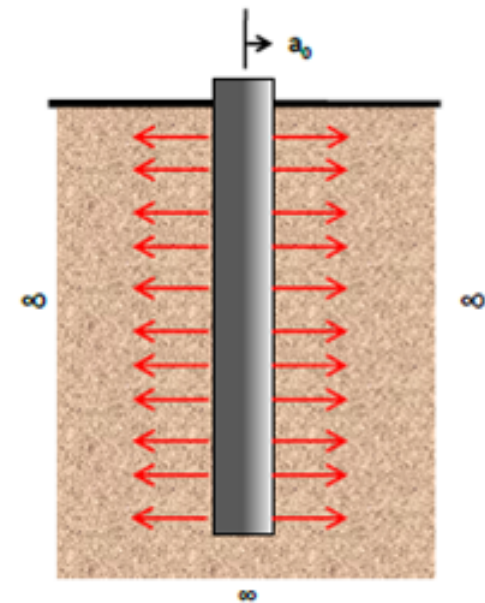

ACTUAL PROBLEM

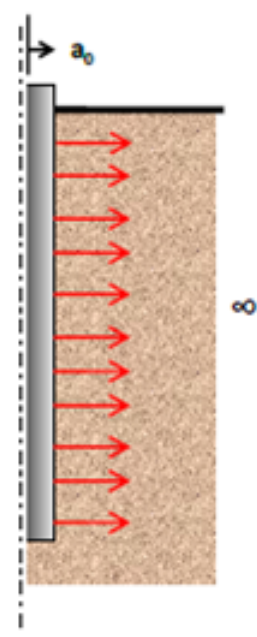

AXISYMMETRY

\section{Gambar 3 . Model pressuremeter dalam keadaan aktual dan} anggapan aksial simetri [Jeremic, 2008].

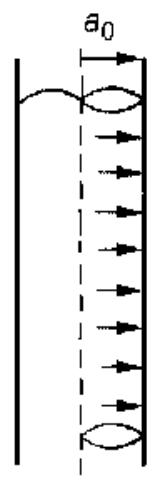

(a)

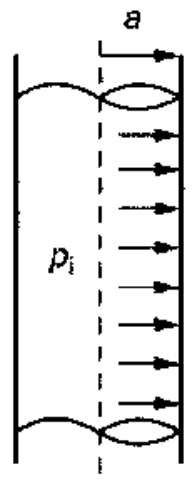

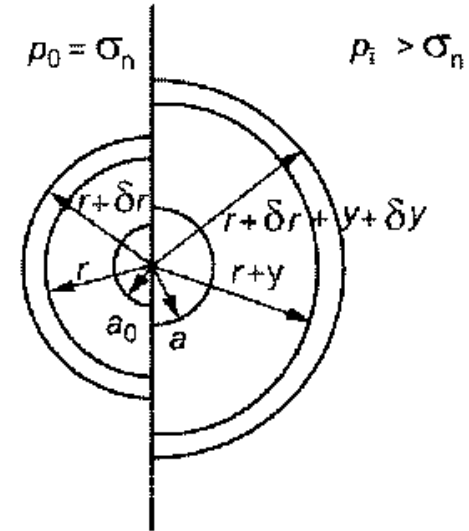

(b)

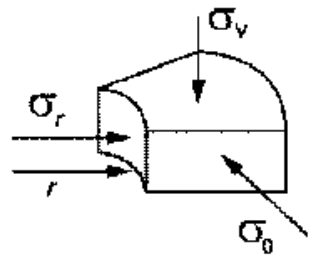

(c)

(a) pengembangan rongga silinder.

(b) pengembangan suatu elemen pada radius $r$.

(c) tegangan yang bekerja pada suatu elemen.

Gambar 4. Definisi yang dipergunakan dalam analisa pengembangan rongga

[Clarke, 1995]

Pada awalnya, radius rongga adalah $a_{o}$ untuk volume rongga $V_{o}$ dan tegangan didalam rongga $\mathrm{p}_{\mathrm{o}}$ yang sama dengan tegangan horizontal total dilapangan $\sigma_{h \boldsymbol{h}}$, sebagaimana digambarkan dalam gambar 4 diatas. $\mathrm{D}$ isemua tempat dalam material yang 
mengelilingi komponen tegangan radial dan tegangan keliling adalah tekan dan besarnya $=p_{o}$. Tegangan didalam rongga kemudian ditambahkan sampai sebesar $p_{i}$ dan radius rongga mencapai $a_{i}$. Suatu titik tipikal dalam material kontinum sekarang mempunyai koordinat radial $r$, bergerak keposisi ini ini dari posisi asalnya $r_{o}$. Dengan menggunakan sistem koordinat silinder, perubahan bentuk dalan arah aksial, radial dan keliling diberikan notasi $s_{g} s_{r}$ dan $s_{\theta}$. Tinjau sebuah elemen yang mengembang $\mathrm{r}+\mathrm{y}$ dan tebalnya bertambah sebesar $0 x+\delta y$ sementara tekanannya bertambah dari $p_{o}$ ke $p_{i}$. Dalam bagian awal dari pembebanan dianggap tanah berperilaku elastis dan mengikuti hukum Hooke sampai awal leleh. Dengan menggunakan teori strain kecil untuk awal fase pembebanan elastis, definisi perubahan bentuk adalah :

$$
\varepsilon_{r}=\frac{\delta y}{\delta r}
$$

dan

$$
\varepsilon_{\theta}=-\frac{y}{r^{r}}
$$

$r$ adalah koordinat radial dan $y$ perpindahan kearah radial (dianggap kecil bila dibandingkan dengan $r$ ) dari titik material dalam massa tanah.

Variabel yang diukur dalam percobaan hanya tekanan rongga (cavity pressure) $p$ dan radius rongga $a$. Perubahan bentuk yang terjadi dalam arah keliling pada dinding rongga disebut sebagai cavity strain (perubahan bentuk rongga) dan didefinisikan sebagai:

$$
\varepsilon_{c}=\frac{a \quad a_{Q}}{a_{\sigma}}
$$

Persamaan ini adalah untuk perubahan bentuk yang kecil, untuk perubahan bentuk yang besar digunakan persamaan keseimbangan yang dinyatakan dalam tegangan total radial dan tangensial sebagai berikut :

$$
\frac{d \sigma_{r}}{d r^{r}}+\frac{\sigma_{r}-\sigma_{\theta}}{r^{2}}-\mathbf{0}
$$

Didalam gambar 5 diperlihatkan rongga dalam keadaan yang belum mengembang, kemudian mengembang tetapi masih dalam daerah elastis dan rongga yang mengembang dan sudah masuk dalam daerah plastis. 

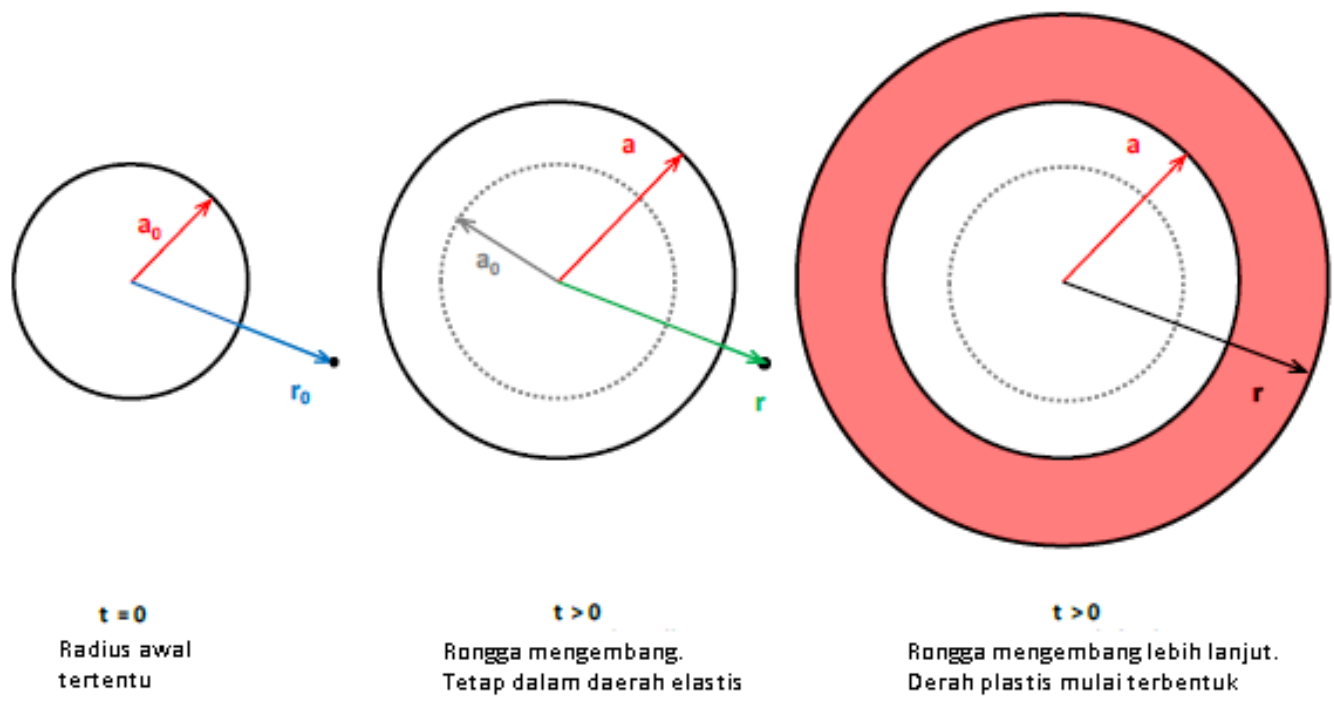

Gambar 5. Ilustrasi secara skematis dari rongga yang mengembang pada waktu yang berbeda-beda untuk kasus material elastis-plastis [Jeremic, 2008].

\section{Tanah elastis}

Untuk sebuah rongga silinder yang mengembang dalam material yang elastis isotropis akan memenuhi Hukum Hooke, tegangan dan perubahan bentuk yang utamanya dinyatakan dalam hubungan sebagai berikut :

$$
E\left[\begin{array}{c}
\Delta \varepsilon_{r} \\
\Delta \varepsilon_{\theta} \\
\Delta \varepsilon_{z}
\end{array}\right]=\left[\begin{array}{ccc}
\ldots 1 . . & -v \ldots . & -v \\
-v . . & . .1 \ldots & -v \\
-v . . & -v \ldots & \ldots 1
\end{array}\right]\left[\begin{array}{c}
\Delta \sigma_{r} \\
\Delta \sigma_{\theta} \\
\Delta \sigma_{z}
\end{array}\right]
$$

Dimana E adalah modulus elastisitas dan $v$ adalah rasio Poisson. Karena bidangnya simetri, perubahan bentuk vertikal $\delta \varepsilon_{z}=0$, sehingga

$$
E\left[\begin{array}{l}
\Delta \varepsilon_{r} \\
\Delta \varepsilon_{\theta}
\end{array}\right]=\left[\begin{array}{cc}
. .\left(1-v^{2}\right) \ldots & \ldots\left(-v-v^{2}\right) \\
\left(-v-v^{2}\right) \ldots & \ldots\left(1-v^{2}\right)
\end{array}\right]\left[\begin{array}{c}
\Delta \sigma_{r} \\
\Delta \sigma_{\theta}
\end{array}\right]
$$

Dengan menggabungkan persamaan (1) - (4) dan (6) diperoleh persamaan diferensial :

$$
r^{2} \frac{d^{2} y}{d r^{2}}+r \frac{d y}{d r}-y=0
$$

Kondisi batasnya adalah 


$$
\begin{array}{ll}
\mathrm{y}=0 & \text { untuk } \mathrm{r}=\infty \\
\mathrm{y}=\left(\mathrm{a}-\mathrm{a}_{\mathrm{o}}\right) & \text { untuk } \mathrm{r}=\mathrm{a}
\end{array}
$$

Perubahan bentuk dan tegangan dalam tanah adalah

$$
\begin{aligned}
& y=\varepsilon_{c} \frac{a_{o} \cdot a}{r} \\
& \Delta \sigma_{r}=\sigma_{r}-\sigma_{h o}=2 G \varepsilon_{c} \frac{a_{o} a}{r^{2}} \\
& \Delta \sigma_{\theta}=\sigma_{\theta}-\sigma_{h o}=2 G \varepsilon_{c} \frac{a_{o} a}{r^{2}}
\end{aligned}
$$

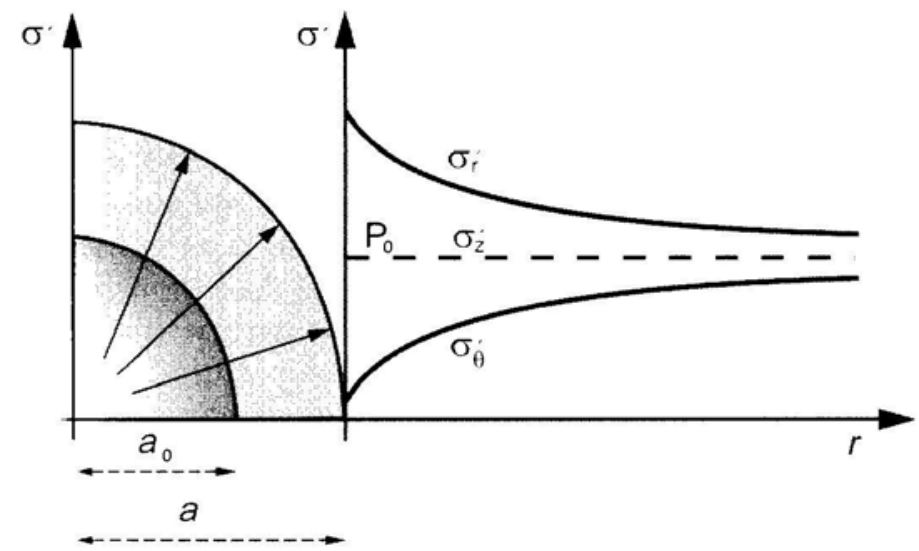

Gambar 6. Tegangan sekeliling rongga slinder yang mengembang dalam tanah elastis [Schnaid, 2009].

dimana $\mathrm{G}$ adalah modulus geser dari material yang elastis dan $\sigma_{\text {ho }}$ adalah tegangan horizontal dilapangan, tegangan rata-rata tetap konstan dalam daerah elastis dan diharapkan tidak ada tegangan pori berlebih yang terjadi selama pengembangan (lihat gambar 6). Pada dinding rongga, $r=a$, dan $\sigma_{r}=p$. Karena $\left(a_{o} / a\right)$ adalah bilangan yang kecil, seringkali diabaikan sehingga persamaan (10) menjadi

$$
\mathrm{p}-\sigma_{h}=2 \mathrm{G} \varepsilon_{c}
$$

Jadi, modulus geser tanah dilapangan dapat ditentukan dengan sederhana dengan mengukur pergerakan dinding rongga sedangkan tekanan rongga bertambah menjadi diatas $\sigma_{h a}$ :

$$
G=\frac{1}{2} \frac{d p}{d \varepsilon_{c}}
$$


Modulus tanah dapat dinyatakan juga dalam perubahan volume (volumetric strain) :

$$
G=V_{o} \frac{d p}{d V}
$$

Sebagaimana dinyatakan oleh Mair \& Wood (1987), pengembangan rongga kelihatannya sebagai proses penekanan, berubah secara keseluruhan menjadi proses geser.

\section{Analisa tak terdrainasi dalam material elastis-plastis}

Analisa tak terdrainasi menganggap tidak terjadi perubahan volume dalam tanah dan kecepatan pembebanan tidak mempengaruhi respon dari tanah. Semua elemen disekeliling rongga, pada setiap radius mengalami deformasi yang sama dalam polanya tetapi berbeda dalam besarnya. Alur tegangan dari elemen tanah disekeliling rongga yang mengembang secara skematis dapat dilihat pada gambar 7 dibawah ini darimana solusi pengembangan rongga dapat dianggap berdasarkan perilaku tegangan regangan dan kekuatan dari lempung (misalkan Gibson \& Anderson, 1961; Palmer, 1972).

Titik A, awalnya ada digaris pusat dari pressuremeter sebelum instalasi, dibebani secara elastis dan kemudian plastis selama pengembangan. Elemen antara A dan C telah berubah bentuk secara plastis, titik E terletak pada batas elastis-plastis pada tahap ini, sedangkan material diluar E masih tetap elastis.

Solusi yang pasti untuk tegangan geser $\tau$ pada regangan rongga adalah (Baguelin et al., 1972; Ladanyi, 1972; Palmer, 1972) :

$$
\tau=\frac{1}{2} \varepsilon_{c}\left(1+\varepsilon_{c}\right)\left(2+\varepsilon_{c}\right) \frac{d p}{d \varepsilon_{c}}
$$

dengan memasukkan regangan geser dalam dinding rongga kurang lebih $2 \varepsilon_{c}$.

Untuk nilai regangan yang kecil :

$$
\tau \approx e_{c} \frac{d \rho}{d s_{c}}
$$

Persamaan (16) dapat ditulis dalam regangan volume sebagai :

$$
\tau=\frac{d p}{d\left[\ln \left(\frac{\Delta V}{V}\right)\right]}
$$

Biasanya dengan mengacu kepada solusi dari Palmer, pernyataan ini memungkinkan untuk membuat kurva pressuremeter sub-tangent, yang menyatakan tegangan geser sama dengan kemiringan kurva tekanan dan regangan volume. Untuk tanah yang elastis dan 
plastis sempurna, harga $\tau$ adalah tetap dan sama dengan kuat geser tak terdrainasi $\mathrm{s}_{\mathrm{u}}$, lihat gambar 8 .
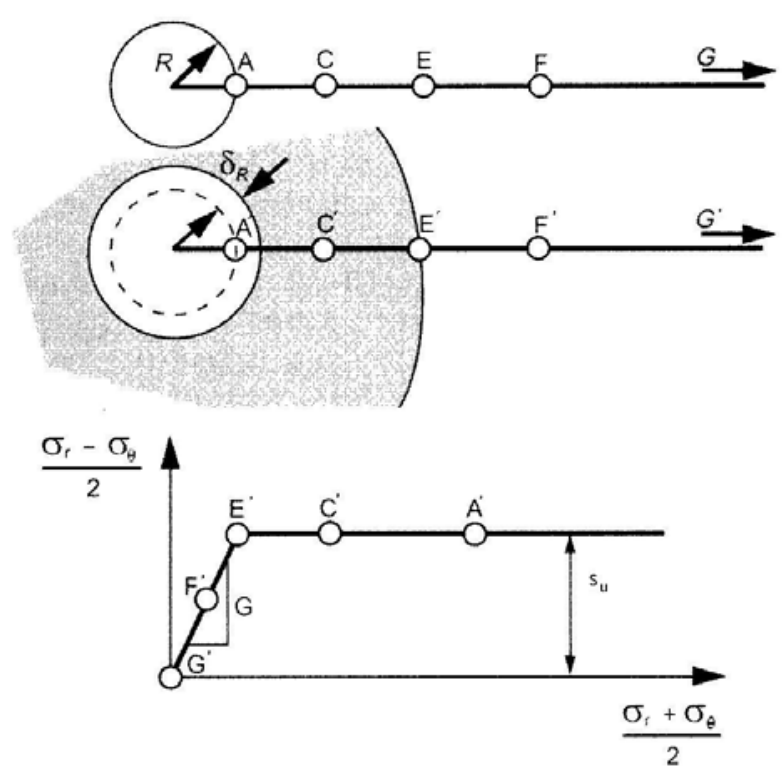

Gambar 7. Alur tegangan tak terdrainasi disekeliling probe pressuremeter yang mengembang [Schnaid, 2009].
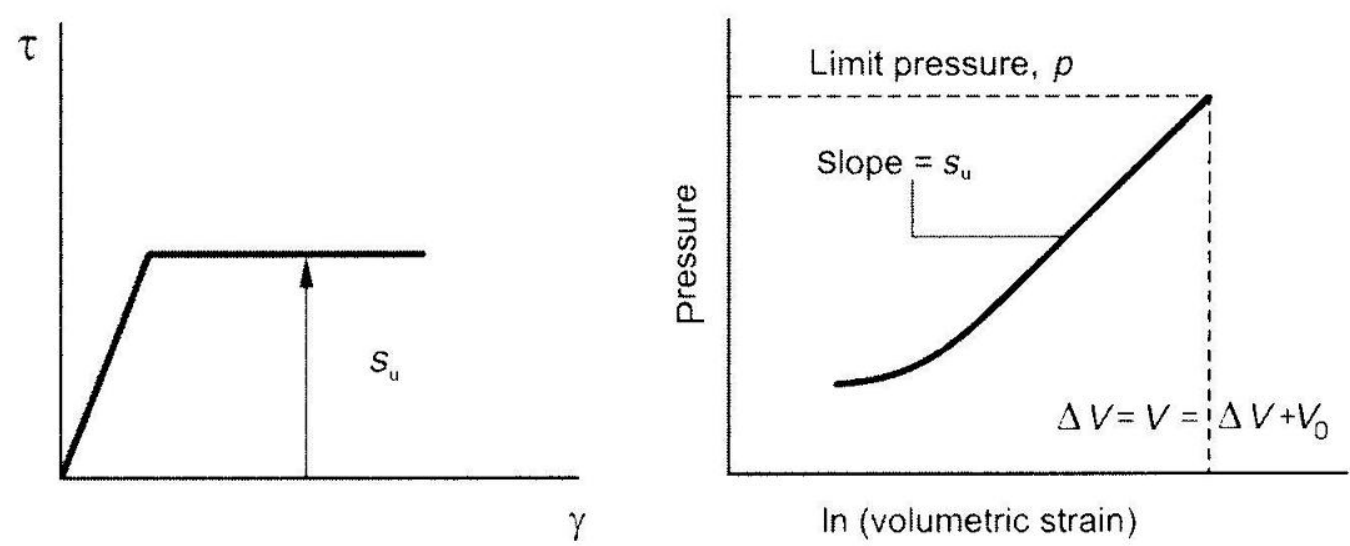

Gambar 8. Kuat geser tak terdrainasi dari uji pressurementer dalm lempung [Schnaid, 2009].

Sulusi untuk kondisi ini pertama kali dipresentasikan oleh Gibson \& Anderson (1961). Selama pengembangan, tanah memberikan respon sebagai material yang elastis sampai awal pemuluran (yielding) pada dinding rongga yang terjadi bila :

$$
p=\sigma_{h \sigma}+s_{u}
$$

Penggunaan Teori Pengembangan Rongga dalam Uji Menard Pressuremeter (Ibrahim Surya) 
Pada tahap ini, regangan elastis kecil adalah :

$$
\frac{\Delta V}{V} \approx \frac{\Delta V}{V_{Q}}=\frac{s_{u}}{G}
$$

Selagi tekanan rongga bertambah melebihi tegangan pemuluran (yield stress) didefinisikan sebagai persamaan (18), daerah plastis terbentuk disekitar rongga yang mengembang. Dalam daerah ini perubahan tekanan dapat diperoleh dengan mengintegrasikan persamaan (17) terhadap $\ln (\Delta V / V$ yang menghasilkan :

$$
p=\sigma_{n 0}+s_{u}\left[1+\ln \left(\frac{G}{s_{u}}\right)+\ln \left(\frac{\Delta V}{V}\right)\right]
$$

Ada suatu kondisi batas untuk persamaan (20) yaitu nilai maksimum ${ }^{\Delta V} / V$ adalah 1 ; yaitu bila perubahan volume sama dengan volume sekarang seperti diperlihatkan pada gambar 8 .

Tekanan pada titik tadi dikenal sebagai limit pressure (tekanan batas), $\mathrm{p}_{\mathrm{L}}$ :

$$
p_{L}=\sigma_{h 0}+s_{u}\left[1+m\left(\frac{G}{s_{w}}\right)\right]
$$

Persamaan ini, telah disampaikan oleh Menard (1957), yang memperlihatkan bahwa batas tekanan rongga sangat tergantung pada kuat geser tak terdrainasi, juga pada kekakuan geser dari tanah.

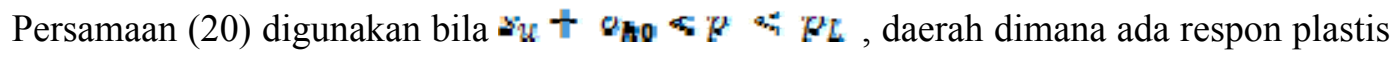
pada uji pressuremeter. Persamaan (19) dapat ditulis juga dalam bentuk :

$$
p=p_{L}+s_{u} \ln \left(\frac{\Delta V}{V}\right)
$$

\section{Analisa terdrainasi dalam material elastis-plastis}

Dalam analisa terdrainasi, tanah dianggap sebagai material isotropis elastisplastis sempurna dan berperilaku elastis dan mengikuti Hukum Hooke sampai awal titik pemuluran (yielding point) yang ditentukan oleh kriteria Mohr-Coulomb. Berhubung geser terjadi di bawah kondisi drainasi tanpa ada tekanan pori berlebih disekeliling rongga yang sedang mengembang, perubahan volume akan terjadi. Analisa hasil percobaan yang gagal dalam memperhitungkan perubahan volume dianggap salah dan tidak dapat dipergunakan dalam interpretasi.

Dengan merujuk pada gambar 9, selagi tekanan didalam rongga meningkat, tanah disekelilingnya akhirnya mengalami pemuluran dan daerah plastis terbentuk disekeliling 
rongga. Ukuran daerah plastis antara titik A dan $\mathrm{E}$ dapat ditentukan, dengan titik $\mathrm{E}$ terletak pada batas elasti-plastis.
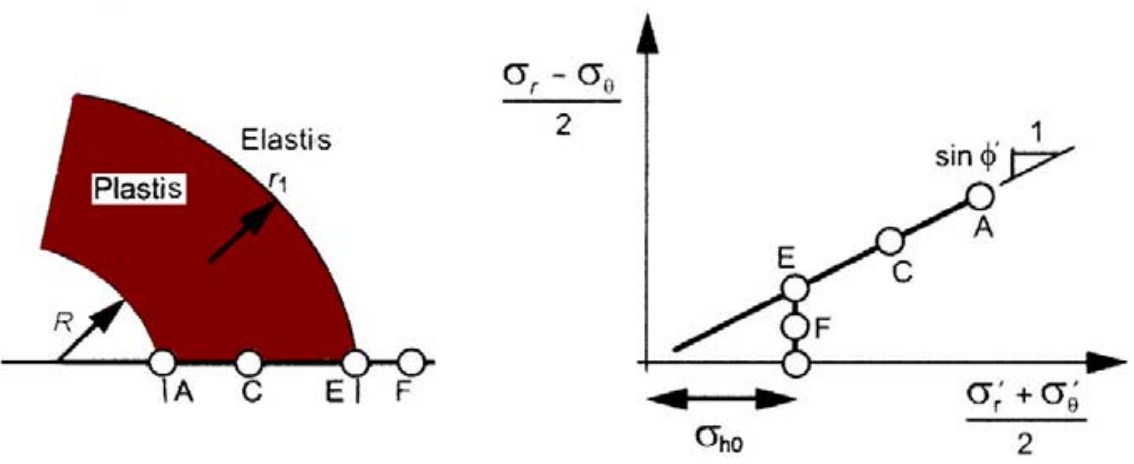

\section{Gambar 9. Alur tegangan terdrainasi sekeliling probe pressuremeter yang mengembang [Schnaid, 2009].}

Hughes et al. (1977) menganggap bahwa kecepatan perubahan volume tetap selama pengembangan rongga dan menghasilkan sudut geser tanah dan dilatansi dari hasil uji pembebanan pressuremeter. Dengan menganggap kelongsoran dipengaruhi kriteria Mohr - Coulomb :

$$
\frac{\sigma_{r}{ }^{\prime}}{\sigma_{\theta}{ }^{\prime}}=\frac{1-\sin \phi^{\prime}}{1+\sin \phi^{\prime}}
$$

Setelah anggapan kriteria kelongsoran dibuat, perlu didefinisikan bentuk dari daerah plastis yang potensial, yang dinyatakan dalam bentuk "aturan aliran" (flow rule) menghubungkan arah dari pertambahan regangan plastis dengan keadaan tegangan yang sekarang. Penggunaan hukum tegangan dilatansi Rowe menghasilkan persamaan berikut :

$$
\frac{1+\sin \varphi^{\prime}}{1-\sin \varphi^{\prime}}=\left(\frac{1+\sin \psi}{1-\sin \psi}\right)\left(\frac{1+\sin \phi_{c v}{ }^{\prime}}{1-\sin \phi_{c v}{ }^{\prime}}\right)
$$

dimana $\psi$ adalah sudut dilasi tanah dan $\Phi^{\prime \prime} w$ adalah sudut geser keadaan kritis (critical state). Ini mengikuti konsep, bila pasir dengan kepadatan medium dan pasir padat bila diberi beban geser akan terjadi dilasi, memberikan kepada tanah suatu tahanan geser yang dihasilkan $\Phi_{w}^{\prime \prime}$ Yang timbul dan sudut dilasi yang timbul $\psi$ :

$$
\sin \psi=-\frac{d \varepsilon_{v}}{d \gamma}
$$

dimana $d s_{y}$ adalah perubahan dalam regangan volume. Tegangan utama, regangan volume dan regangan geser dapat digabung menjadi : 


$$
\frac{\sigma_{r}^{\prime}}{\sigma_{\theta}^{\prime}}=\left(\frac{1+\sin \phi_{c v}^{\prime}}{1-\sin \phi_{c v}^{\prime}}\right)\left(\frac{1-d \varepsilon_{v} / d \gamma}{1+d v / d \gamma}\right)
$$

Awal pemuluran pada dinding rongga dalam pengembangan terdrainasi :

$$
p-u_{0}=\sigma_{h 0}^{s}\left(1+\sin \phi^{\prime}\right)
$$

dimana $u_{\mathbf{v}}$ adalah tegangan pori dilapangan dan $\sigma^{\prime}{ }_{\mathbf{h o}}$ adalah tegangan horizontal efektif dilapangan (in situ). Solusi analitis dari kurva pengembangan rongga dalam daerah plastis dapat didekati dengan rumus dari Hughes et al, 1977 :

\section{团 EMBED Equation.DSMT4 因团图}

dimana A adalah konstanta. Persamaan (28) menyatakan hasil pressuremeter digambarkan sebagai tekanan rongga efektif terhadap regangan volume dalam skala logaritmis yang menghasilkan sebuah garis lurus dengan kemiringan S yang dinyatakan oleh persamaan :

$$
S=\frac{(1+\sin \psi) \sin \phi^{\prime}}{1+\sin \phi^{\prime}}
$$

Nilai $\Phi^{\prime} \& \psi$ dari hasil pengukuran kemiringan pressuremeter S dan sudut geser keadaan kritis (critical state) diberikan oleh hukum tegangan dilatansi Rowe persamaan (24)

$$
\begin{aligned}
\sin \phi^{\prime} & =\frac{S}{1+(S-1) \sin \phi_{c v}^{\prime}} \\
\sin \psi & =S+(S-1) \sin \phi_{c v}^{\prime}
\end{aligned}
$$

\section{Uji pressuremeter dalam lempung}

Dibawah ini akan diberikan penggunaan utama dari teori pengembangan rongga dalam interpretasi uji pressuremeter dalam lempung. Uji pressuremeter terutama digunakan untuk memperkirakan modulus geser, modulus tangen Menard, tegangan horizontal insitu, kuat geser tak terdrainasi dan koefisien konsolidasi horizontal.

\section{Modulus tangen Menard dan modulus geser}

Yang biasa dilakukan dalam uji pressuremeter adalah evaluasi modulus tanah (Wroth, 1982). Seperti diketahui, interpretasi modulus tanah dari uji pressuremeter dan penggunaan modulus ini dalam perancangan pondasi adalah proses yang kompleks, karena modulus bervariasi dengan tingkat tegangan dan regangan amplitudo (Wroth et al, 1979; Jamiolkowski et al, 1985; Belotti et al, 1986; Tatsuoka et al,1997).

Dalam metode Menard kekakuan dari tanah diperoleh dari segmen elastis yang pertama dari kurva tekanan-volume rongga. Daerah elastis didefinisikan dalam batas- 
batas yang ditentukan oleh titik $\mathrm{P}_{\mathrm{o}}$ pada gambar 10 dimana membran telah menyentuh dinding lubang bor dan titik yang ditandai pada awal perilaku plastis dari tanah yang paling dekat dengan pressuremeter. Meskipun titik-titik ini sulit untuk ditentukan, modulus tangen dari Menard, $\mathrm{E}_{\mathrm{m}}$ diambil dari kemiringan didaerah plastis dengan menggunakan solusi dari Lame :

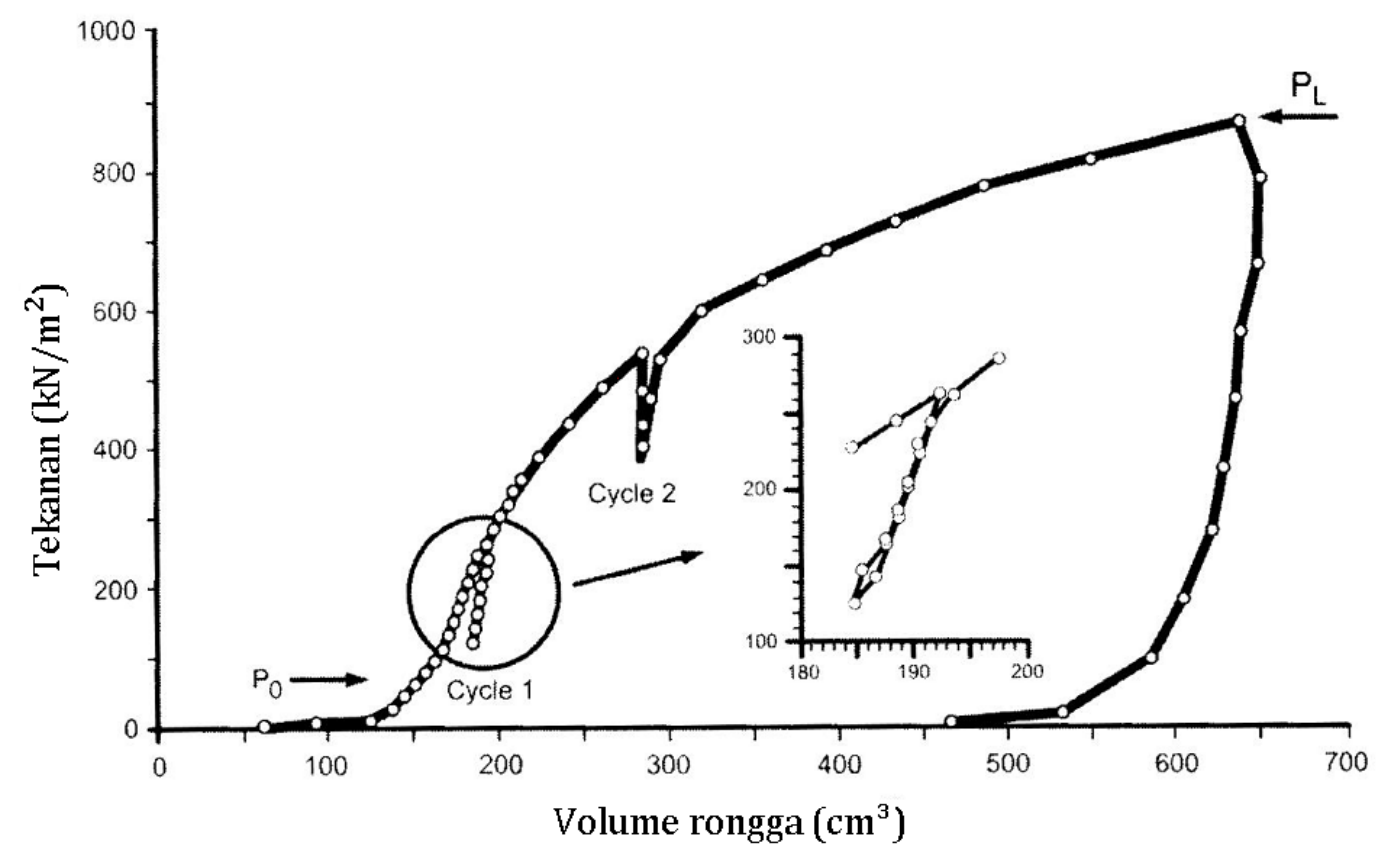

Gambar 10. Kurva hasil uji pressuremeter Menard [Schnaid, 2009].

$$
E_{m}=2(1+v)\left[V_{o}+\frac{V_{B}-V_{A}}{2}\right] \frac{d p}{d V}
$$

dimana $\mathrm{V}_{\mathrm{o}}$ adalah volume awal dari probe. Dalam lempung, deformasi plastis dimulai dari tahap awal percobaan dan karenanya $E_{m}$ memberikan harga perkiraan yang rendah pada modulus insitu. Dalam analisa uji pressuremeter, dianggap alat pressuremeter sebagai suatu rongga silinder yang panjang dan mengembang secara radial dam kondisi regangan membidang (plane strain). Karenanya kalau probe mengembang dalam material yang linier elastis isotropis, modulus geser $\mathrm{G}$ sama dengan separuh dari kemiringan kurva tekanan-volume :

$$
G=\frac{1}{2} \frac{d p}{d \varepsilon_{c}}
$$

Pendekatan ini berarti setiap pelepasan beban dari suatu rongga yang mengembang membawa tanah disekeliling dibawah permukaan pemuluran yang baru mengembang 
kedalam zona dimana regangannya kecil sebagaimana diperlihatkan oleh alur pembebanan CDE dalam gambar 11 (b).

Dalam melaksanakan proses unload -reload, perlu diperhatikan bahwa proses ini tetap dalam daerah yang elastis.Untuk tanah elastis -plastis sempurna Tresca, teori pengembangan rongga dapat dipergunakan untuk menunjukan bahwa besarnya perubahan dalam tekanan rongga tidak melebihi (Wroth, 1982) :

$$
\Delta p_{m a k s}=2 s_{z}
$$

dimana $\mathrm{s}_{\mathrm{u}}$ adalah kuat geser tak terdrainasi dari tanah

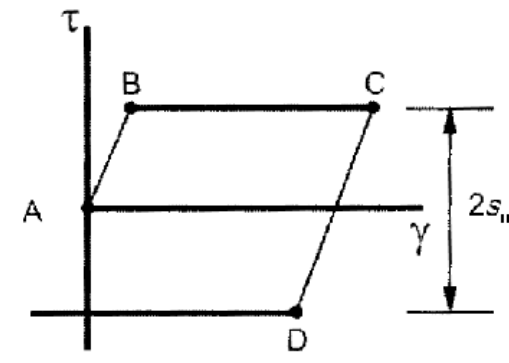

(a)

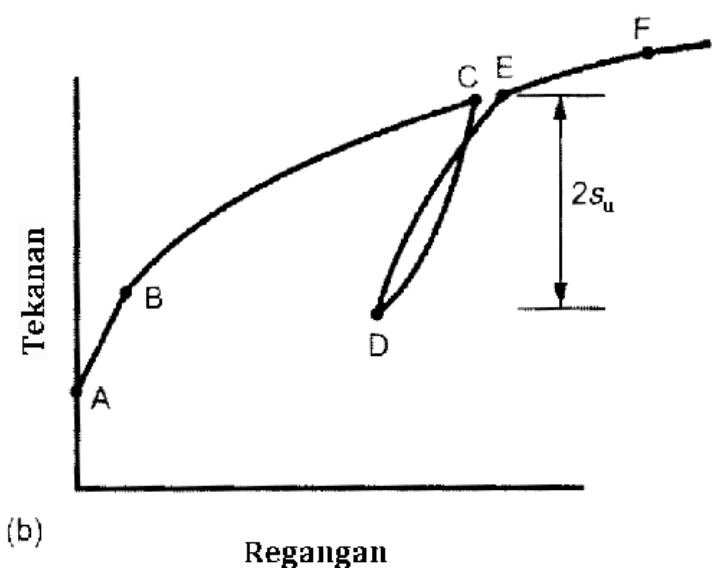

Gambar 11. Rentang respon elastis dalam lempung elastis-plastis sempurna: (a) alur tegangan Geser dan (b) kurva uji pressuremeter [Wroth, 1982].

Regangan yang terjadi pada elemen tanah pada jarak yang berbeda dari pressuremeter berbanding terbalik dengan jari-jari kuadrat dalam uji tak terdrainasi dan karenanya suatu patokan regangan geser perlu ditentukan yang mewakili modulus geser unload-reload, $\mathrm{G}_{\mathrm{ur}}$. Nilai patokan ini seringkali diambil sebagai regangan yang bekerja pada permukaan pressuremeter.

Muir Wood (1990) menyelidiki variasi $\mathrm{G}_{\mathrm{ur}}$ dengan amplitudo regangan geser dalam tanah lempung. Dalam pressuremeter dimungkinkan untuk mendefinisikan modulus sekan $G_{s}{ }^{p}=\left(\psi-\sigma_{h 0}\right) / 2 \varepsilon$ dan modulus tangen $G_{t}{ }^{p}=\frac{1}{2} d \psi / d \varepsilon$. Ini sama dengan uji dilaboratorium yang memungkinkan untuk mendefinisikan modulus sekan $G_{s}=\tau / \gamma$ dan modulus tangen $G_{t}=d \tau / d \gamma$, dimana $\tau$ adalah tegangan geser. Dengan definisi-definisi diatas dapat dilihat bahwa : 


$$
\begin{aligned}
& G_{t}=G_{s}+\gamma \frac{d G_{s}}{d \gamma} \\
& G_{t}{ }^{p}=G_{s}{ }^{p}+2 \varepsilon \frac{d G_{s}{ }^{p}}{2 d \varepsilon} \\
& G_{s}=G_{t}{ }^{p}=G_{s}{ }^{p}+2 \varepsilon \frac{d G_{s}{ }^{p}}{2 d \varepsilon}
\end{aligned}
$$

Jadi, menurut Muir Wood (1990), modulus tangen yang diukur dari kurva pressuremeter adalah sama dengan modulus sekan yang ditentukan dari uji laboratorium konvensional. Ini memungkinkan hasil uji pressuremeter dihubungkan dengan hasil uji yang lain dengan menggunakan model degradasi yang dirancang untuk menerangkan hubungan antara $G$ dan g (Schnaid, 2009).

\section{Tegangan total horizontal di lapangan}

Dalam pressuremeter Menard, pengukuran yang berkenaan dengan dimulainya segmen linier yang elastis sebagai indikasi patokan dari tekanan rongga, hal ini tidak mempunyai dasar yang kuat sebagaimana disampaikan oleh Mair \& Wood (1987), karena proses pembuatan lubang bor membiarkan tanah tanpa ada yang menahannya. Suatu pengukuran tekanan awal dalam tanah yang dalam keadaan unloading sebelum dilakukan uji pressuremeter Menard tidak dapat dikatakan dalam keadaan tidak terganggu. Untuk menanggulangi hal ini Marsland \& Randolph (1977) mengusulan suatu teknik untuk memperkirakan nilai tekanan awal sebagai patokan, yang secara bersamaan berdasarkan kuat geser dan tegangan pemuluran dari lempung. Selama pengembangan tegangan pemuluran pada dinding rongga sama dengan penjumlahan $\sigma_{\mathrm{h} 0}$ dan $\mathrm{s}_{\mathrm{u}}$ dan diidentifikasikan sebagai perubahan kemiringan dari kurva uji :

$$
p=\sigma_{h 0}+s_{u}
$$

Suatu pendekatan iteratif dibutuhkan untuk memaksa terjadinya konsistensi antara tegangan pemuluran yang diukur dalam kurva $\mathrm{p}$ vs $\varepsilon_{c}$ dan jumlah perkiraan tegangan horizontal awal dan kuat geser tanah tak terdrainasi.

\section{Kuat geser tak terdrainasi}

Ada beberapa cara berbeda untuk memperkirakan kuat geser dari uji pressuremeter dalam lempung dalam tegangan total seperti dari Gibson \& Anderson (1961); Palmer (1972); Houlsby \& Withers (1988); Jefferies (1988); dan untuk analisa 
dalam tegangan efektif dari Yu \& Collins (1998) baik untuk segmen pembebanan dan pelepasan beban dari kurva uji pressuremeter.

Untuk analisa pembebanan (loading), metode Gibson dan Anderson (1961) menganggap tanah berperilaku sebagai material Tresca yang elastis plastis sempurna. Solusi analitis untuk pengembangan rongga dalam tahap plastis dari suatu rongga silinder yang panjang diturunkan dari rumus :

$$
p=\sigma_{h 0}+s_{u}\left[1+\ln \left(\frac{G}{s_{u}}\right)+\ln \left(\frac{\Delta V}{V}\right)\right]
$$

dimana $\quad p$ adalah tekanan total pressuremeter, $\sigma_{h 0}$ tegangan horizontal dilapangan, $s_{u}$ kuat geser tak terdrainasi $G$ modulus geser. Regangan volume adalah :

$$
\frac{\Delta V}{V}=\frac{a^{2}-a_{0}^{2}}{a^{2}}
$$

Nilai a dan $\mathrm{a}_{0}$ adalah radius yang sekarang dan radius awal. Analisa dengan memakai persamaan (20) menyatakan secara tidak langsung bahwa uji selfboring pressuremeter yang dilaksanakan dalam tanah yang plastis sempurna akan menghasilkan sebuah garis lurus dalam kurva hubungan antara tekanan dalam ronggga terhadap logaritma regangan volume, lihat gambar 12(a).

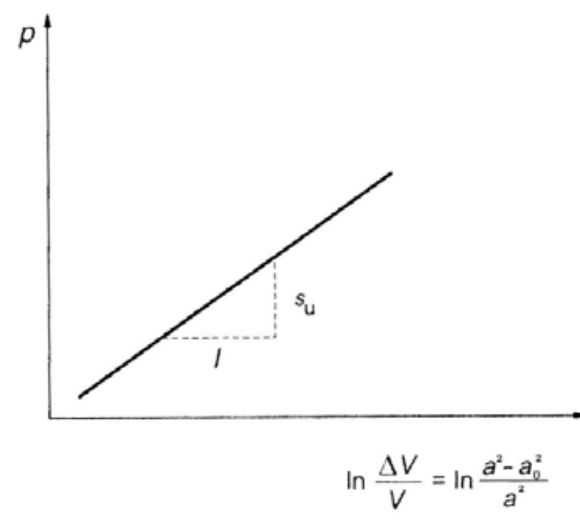

(a)

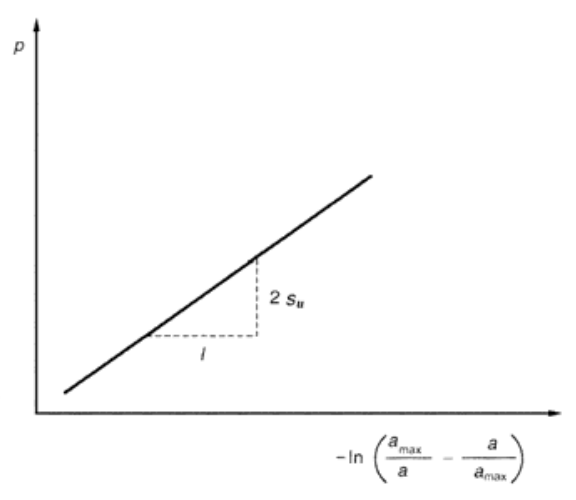

(b)

Gambar 12. (a) Analisa pembebanan secara grafis uji pressuremeter dalam lempung [Gibson dan Anderson, 1961].

(b) Analisa unloading secara grafis uji pressuremeter dalam lempung [Jefferies, 1988].

Untuk analisa unloading Jefferies (1988) menyatakan pengembangan pressuremeter sebagai tekanan rongga total, $p_{\max }$ diikuti dengan kontraksi yang kecil. 
Awalnya kurva unloading pressuremeter adalah linier elastis dan dapat diterangkan dengan rumus ini :

$$
p-p_{\max }=2 G\left(\frac{a-a_{\max }}{a_{\max }}\right)
$$

dimana $a_{\text {max }}$ adalah perpindahan maksimum yang mendekati akhir pembebanan. Kurva unloading plastis dijelaskan dalam rumus :

$$
p-p_{\max }=-2 s_{u}\left[1+\ln \left(\frac{G}{2 s_{u}}\right)\right]-2 s_{u}\left(\frac{a_{\max }}{a}-\frac{a}{a_{\max }}\right)
$$

dengan menganggap bahwa kuat geser tak terdrainasi pada unloading sama dengan pada loading. Menurut metode analisa pembebanan Gibson \& Anderson, penyelesaian teoritis didefinisikan oleh persamaan (40) yang menyarankan hasil uji pressuremeter unloading harus digambarkan dalam hubungan antara tekanan rongga $p$ vs $-\ln \left(a_{\max } / a-a / a_{\max }\right)$ sebagaimana digambarkan dalam gambar 12 (b). Di dalam gambar tadi, kemiringan dari bagian yang plastis dari unloading berupa garis lurus yang sama dengan 2 kali kuat geser tak terdrainasi dari tanah, $2 s_{u}$.

\section{Uji pressuremeter dalam tanah pasir}

Hasil uji pressuremeter dalam tanah pasir dapat digunakan untuk memperkirakan nilai modulus geser, tekanan horizontal dilapangan dan kuat geser tanah (sudut geser dan dilasi). Penyelesaian analitis berdasarkan pada analisa regangan kecil, yang memenuhi interpretasi dari uji selfboring pressuremeter dan menganggap pengembangan berlangsung secara perlahan dibawah kondisi drainasi penuh.

\section{Modulus geser}

Hasil uji pressuremeter dapat digunakan untuk menentukan modulus awal dalam uji Menard pressuremeter - lihat persamaan 23 dan modulus geser untuk unload - reload dalam uji selfboring pressuremeter- lihat persamaan 24. Bila pressuremeter dalam material yang isotropis linier, hubungan antara perubahan tekanan efektif rongga dan perubahan regangan rongga telah sangat dikenal; karenanya modulus geser $G$ dapat ditentukan dari kemiringan kurva tekanan vs pengembangan seperti dilihat dari persamaan berikut :

$$
G=\frac{1}{2} \frac{d p}{d \varepsilon_{c}}
$$

Penggunaan Teori Pengembangan Rongga dalam Uji Menard Pressuremeter 


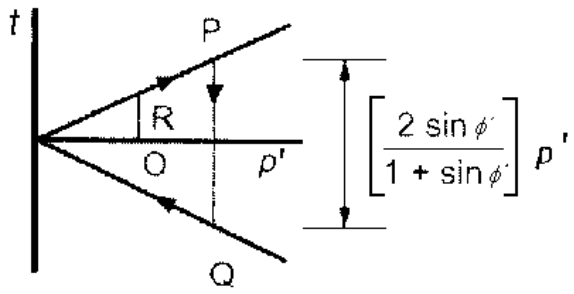

(a)

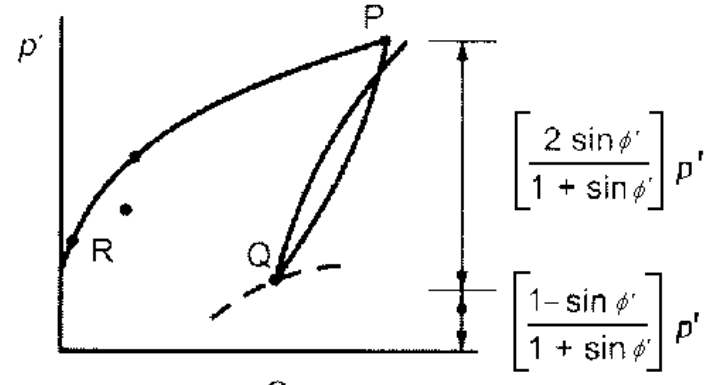

(b) $\varepsilon$

\section{Gambar 13. Rentang respon elastis dalam pasir elastis-plastis sempurna :}

(a) alur tegangan geser dan (b) kurva uji pressuremeter [Wroth, 1982].

Dalam uji pressuremeter ditanah pasir, tegangan efektif rata-rata berubah sebagai fungsi dari tekanan rongga yang digunakan dan jarak dari dinding rongga. Karena kekakuan pada pasir tergantung dari tingkat tegangan dimana pengukuran dilakukan, modulus yang ditentukan dari lekukan unload-reload berturut-turut pada tahap pembebanan yang berbeda dari suatu pengujian diharapkan akan terlihat suatu peningkatan dalam kekakuan (untuk amplitudo geser yang sama) selama pegujian berlangsung.

Di dalam kasus tanah lempung, sangatlah penting untuk meyakinkan pada suatu pengurangan beban pada rongga yang yang mengembang tetap dalam daerah yang elastis, dimana regangan kecil. Wroth (1982) menyarankan besarnya perubahan dalam tegangan efektif rongga selama pengurangan beban elastis tidak melebihi :

$$
\Delta p_{\max }=\frac{2 \sin \phi^{\prime}}{1+\sin \phi^{\prime}}\left(p-u_{0}\right)_{\max }
$$

$\left(p-u_{0}\right)_{\max }$ adalah tekanan efektif rongga dimana pengurangan beban (unloading) terjadi dan $\phi^{\prime}$ sudut geser terdrainasi (dalam regangan membidang). Keadaan batas ini, dinyatakan dengan alur tegangan PQ dalam Gambar 13, dan tergantung dari tekanan rongga efektif dimana pengurangan beban (unloading) dimulai.

\section{Tegangan total horizontal dilapangan}

Walaupun bermacam metode dikembangkan untuk memperkirakan keadaan tegangan dilapangan, tetapi belum memungkinkan untuk menentukan secara akurat tegangan horizontal dalam kebanyakan endapan pasir alami. Sampai saat ini tegangan horizontal dilapangan dalam tanah pasir belum dapat ditentukan secara akurat sekalipun dengan menggunakan uji selfboring pressuremeter (lihat Windle (1976); Fahey (1980); Fahey \& Randolph (1984)). 


\section{Parameter kuat geser terdrainasi}

Di muka telah dibahas penyelesaian analitis untuk regangan kecil pada pengembangan rongga dalam material Mohr-Coulomb yang elastis-plastis sempurna yang memungkinkan sudut tahanan geser dan dilasi dapat ditentukan.

Hughes et al (1977) mengembangkan sebuah metode dimana kurva pengembangan rongga dalam tahap plastis dapat diterangkan dengan persamaan :

$$
\ln \left(p-u_{0}\right)=S \ln \varepsilon_{c}+A
$$

dimana A adalah konstanta dan $\mathrm{S}$ adalah kemiringan dari grafik yang menggambarkan tekanan efektif rongga vs ln regangan volumetric, yang dinyatakan dalam persamaan :

$$
S=\frac{(1+\sin \psi) \sin \phi^{\prime}}{1+\sin \phi^{\prime}}
$$

dimana $\phi^{\prime}$ adalah sudut geser dan $\sin \psi=S+(S-1) \sin \phi_{c v}^{\prime} \psi$ adalah sudut dilasi. Hubungan yang diperlukan untuk mendapatkan nilai $\phi^{\prime}$ dan $\psi$ dari pengukuran kemiringan kurva pressuremeter S dan sudut geser kritis dari tanah diberikan oleh hukum tegangan dilatansi Rowe dalam persamaan :

$$
\begin{aligned}
& \sin \phi^{\prime}=\frac{S}{1+(S-1) \sin \phi_{c v}^{\prime}} \\
& \sin \psi=S+(S-1) \sin \phi_{c v}^{\prime}
\end{aligned}
$$

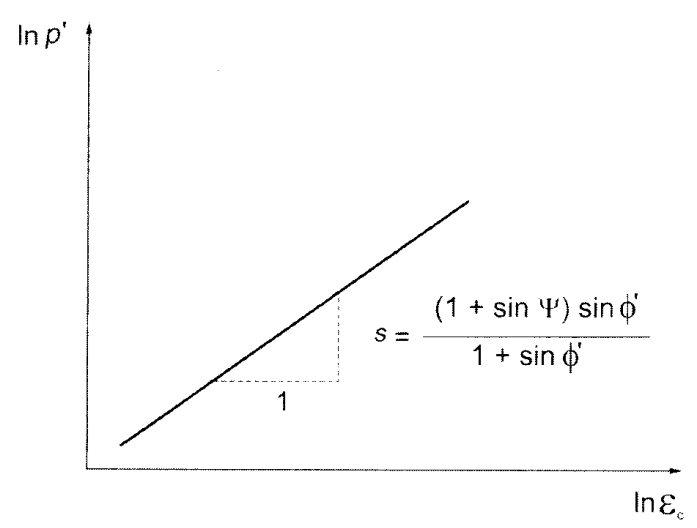

\section{Gambar 14. Grafik pembebanan analisa uji pressuremeter dalam pasir} [Hughes et al, 1977].

Metode ini banyak digunakan dalam pasir dan membutuhkan data pressuremeter digambarkan dalam hubungan antara $\ln p$ vs $\ln \varepsilon_{\mathrm{c}}$,segaimana digambarkan dalam Gambar 14. Dalam gambar tadi, kemiringan dari bagian yang plastis akan menghasilkan 
sebuah garis lurus sebesar $S$, yang akan digunakan untuk menentukan sudut geser dan dilasi dari persamaan (30) dan (31), dengan mengukur atau memperkirakan sudut geser kritisnya.Nilai standar dari $\varnothing_{\mathrm{cv}}{ }^{6}$ dapat dilihat pada tabel 1.

Tabel 1. Nilai standar $\varnothing_{c v}$ [Schnaid, 2009].

\begin{tabular}{|l|l|l|}
\hline \multirow{2}{*}{ Material } & $\begin{array}{l}\text { Bolton } \\
(\mathbf{1 9 7 9 )}\end{array}$ & $\begin{array}{l}\text { Robertson \& Hughes } \\
\mathbf{( 1 9 8 6 )}\end{array}$ \\
\cline { 2 - 3 } & $\varnothing_{\mathbf{c v}}$ & $\varnothing_{\mathbf{c v}}$ \\
\hline Pasir padat,gradasi baik atau kerikil & $35^{\circ}$ & $40^{\circ}$ \\
\hline $\begin{array}{l}\text { Pasir uniform,kepadatan sedang/pasir } \\
\text { kasar }\end{array}$ & $32^{\circ}$ & $34-37^{\circ}$ \\
\hline Lanau pasiran dengan lempung, padat & $32^{\circ}$ & \\
\hline $\begin{array}{l}\text { Pasir halus dan lempung pasiran, } \\
\text { lempung lanauan }\end{array}$ & $30^{\circ}$ & $30-34^{\circ}$ \\
\hline Lempung - shale & $25^{\circ}$ & \\
\hline Lempung (London) & $15^{\circ}$ & \\
\hline
\end{tabular}

Sebagai alternatif yang lain dapat digunakan grafik dari (Mair \& Wood, 1987) lihat gambar 15 untuk menentukan sudut tahanan geser $\varnothing^{\prime}$ dan $\psi$ dengan nilai $\varnothing_{\mathrm{cv}}$

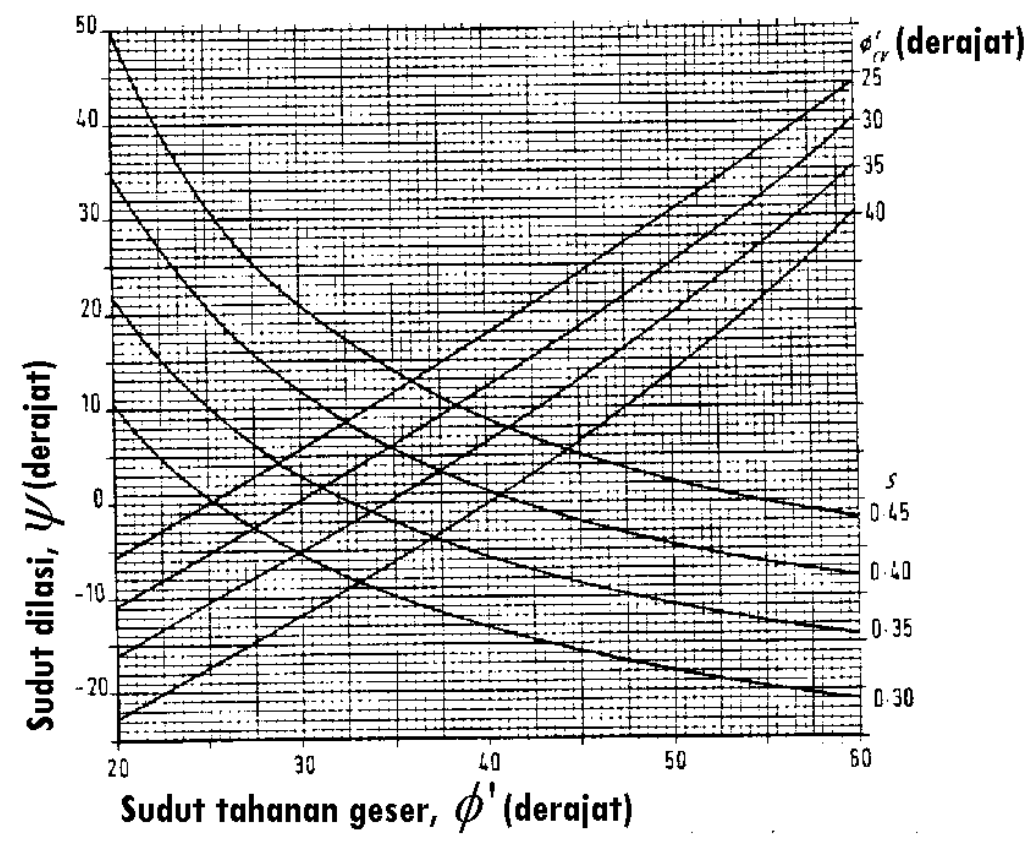

Gambar 15. Grafik untuk uji pres-suremeter dalam tanah pasir dan hubungan dengan parameter lainnya [Mair \& Wood, 1987].

\section{Uji pressuremeter dalam tanah kohesif dan butiran}

Uji penetrasi, seperti SPT dan CPT banyak digunakan dalam interpretasi material tanah tersemenkan, berhubung kesulitan dalam menyatakan perilakunya dengan menggunakan model sederhana dengan beberapa parameter konstitutif, korelasi empirik 
untuk menentukan sifat-sifat tanah seringkali digunakan sebagai opsi yang disukai karena dapat disesuaikan menurut kondisi lokasi yang spesifik utnuk memenuhi standar yang mencerminkan praktek rekayasa regional. Akan tetapi, metoda empiris atau semi empiris tidak dapat memenuhi hasil yang memuaskan dalam material tanah yang berkohesi dan mempunyai sudut geser dalam (c' dan $\varnothing^{\prime}$ ), sehingga tidak dapat ditentukan dari pengujian tunggal sepert dari $\mathrm{q}_{\mathrm{c}}$ atau $\mathrm{N}_{60}$ saja.

Uji pressuremeter muncul sebagai pilihan yang terbaik untuk memeriksa ketepatan dari suatu hasil parameter untuk perancangan dalam tanah yang mempunyai kohesi dan sudut geser. Semua teori untuk interpretasi uji pressuremeter untuk tanah tersebut diatas menggunakan tegangan horizontal di lapangan, kekakuan tanah dan parameter kekuatan tanah: sudut geser dalam, sudut dilasi, dan kohesi yang berkurang dengan perubahan struktur tanah pada regangan geser yang tinggi. Kurva tekanan ekspansi karenanya menggambarkan gabungan dari semua parameter-parameter ini yang tidak dapat diperkirakan secara sendiri-sendiri.

Beberapa metode telah dikembangkan untuk interpretasi uji pressuremeter dalam material berkohesi dan butiran, dengan mempertimbangkan sudut geser dalam maupun kohesi yang tereduksi (Carter et al, 1986; Yu \& Houlsby,1991; Haberfield, 1997; Mantaras \& Schnaid, 2002; Schnaid \& Mantaras, 2003). Berhubung para peneliti terdahulu belum memperhitungkan dampak ikatan antar partikel pada nilai dilasi, solusi dari Mantaras \& Schnaid (2002) dan Schnaid \& Mantaras (2003) telah mempertimbangkan dengan lebih akurat penjelasan mengenai proses pengembangan rongga dalam material berkohesi dan butiran.

Konsep yang diperkenalkan oleh Rowe (1963), bahwa dilatansi plastis terkekang oleh adanya ikatan dalam tanah, telah diselidiki oleh Mantaras \& Schnaid (2002) dan digunakan untuk menjelaskan komponen pertambahan tangensial dan radial plastis. Model tanah dan definisi tegangan \& regangan yang digunakan sama seperti yang digunakan oleh Yu \& Houlsby (1991).

Untuk material tanpa kohesi, persamaan yang diberikan telah disederhanakan seperti yang dipergunakan untuk material butiran dan mengusulkan penyelesaian pendekatan pada $\mathrm{Yu}$ dan Houlsby hubungan tekanan-ekspansi.

Dalam analisa elastis-plastis dalam material dalam material berkohesi dan butiran, tegangan geser dinyatakan oleh 2 parameter - sudut geser dalam dari material $\varnothing$, dan kohesi tereduksi c', sebagaimana dinterpretasikan dari selubung Mohr-Coulomb. 
Kalau tegangan yang dipergunakan bertambah, pemuluran awal akan dimulai pada dinding rongga bila tegangan gesr mencapai selubung longsor:

$$
\sigma_{r}=\frac{2 c^{\prime} \cos \phi^{\prime}}{1-\sin \phi^{\prime}}+\sigma_{\theta} \frac{1+\sin \phi^{\prime}}{1-\sin \phi^{\prime}}
$$

Aturan aliran yang tidak terhubungkan dapat dinyatakan sebagai $\dot{\varepsilon_{\theta}^{p}} / \dot{\varepsilon_{r}^{p}}=-\beta$, dimana $\dot{\varepsilon}_{\theta}^{p}$ dan $\dot{\varepsilon}_{r}^{p}$ adalah komponen plastis dari pertambahan regangan tangensial dan radial. Pertambahan regangan plastis dihitung dengan mengurangi komponen elastis dari regangan total, yang membentuk persamaan :

$$
\beta \dot{\varepsilon}_{r}+\dot{\varepsilon}_{\theta}=\beta \dot{\varepsilon}_{r}^{e}+\dot{\varepsilon}_{\theta}^{e}
$$

Substitusikan nilai komponen regangan elastis yang didefinisikan oleh Hukum Hooke sehingga persamaan menjadi :

$$
\beta \dot{\varepsilon}_{r}+\dot{\varepsilon}_{\theta}=\beta \frac{1-v^{2}}{E}\left[\Delta \sigma_{r}-\frac{v}{1-v} \Delta \sigma_{\theta}\right]+\frac{1-v^{2}}{E}\left[\Delta \sigma_{\theta}-\frac{v}{1-v} \Delta \sigma_{r}\right]
$$

dimana $v$ adalah rasio Poisson.Definisi umum yang diusulkan oleh hukum Rowe, berdasarkan hipotesa pertambahan energi absolut minimum selama geser, dapat diadaptasi tidak hanya mempertimbangkan baik komponen kohesi dan gesekan saja, tetapi juga memperkenankan adanya degrdasi dari kohesi selama geser:

$$
\beta=\frac{\sigma_{r}{ }^{\prime}}{\left[\tan \left(\frac{\pi}{4}+\frac{\phi_{c v}{ }^{\prime}}{2}\right)\right]^{2} \sigma_{\theta}+\frac{2 c_{0}{ }^{\prime}}{\left[1+\varepsilon_{r}-\varepsilon_{\theta}-\gamma_{p}\right]^{n}} \tan \left(\frac{\pi}{4}+\frac{\phi_{c v}{ }^{\prime}}{2}\right)}
$$

dimana $\varepsilon_{\mathrm{r}}$ adalah regangan radial, $\varepsilon_{\theta}$ regangan keliling, $\mathrm{g}_{\mathrm{p}}$ regangan geser berkenaan dengan awal pelumeran dan $\mathrm{c}_{0}$ ' kohesi puncak triaksial Mohr-Coulomb. Perlu diperhatikan bahwa reduksi dalam kohesi antar partikel dinyatakan secara sederhana sebagai sebuah parabola, dinyatakan sebagai sebuah fungsi regangan geser dan asimtotis mendekati nol pada regangan yang besar, sehingga:

$c^{\prime}=\frac{c_{0}{ }^{\prime}}{\left(1+\gamma-\gamma_{p}\right)^{n}}$

n adalah indeks degradasi, dikalibrasikan menggunakan hasil uji laboratorium konvensional dan $\gamma_{p}$ regangan geser puncak dihitung menggunakan hukum Hooke. Dengan menggunakan persamaan (34) untuk menjelaskan aturan aliran dapat mengurangi satu dari batasan yang utama pada formulasi pengembangan rongga klasik. Sebuah harga 
$\mathrm{c}_{0}$ ' puncak dipilih untuk bagian yang elastis dan didalam bagian yang plastis analisa dapat tetap melacak jalannya pengurangan dalam kuat geser yang dihasilkan oleh amplitudo regangan geser desekeliling rongga.

Penyelesaian untuk persamaan-persamaan ini diformulasikan dalam suatu kerangka kerja yang tidak berkaitan dengan plastisitas yang menggunakan metoda Euler untuk memecahkan dua persamaan diferensial secara bersamaan, yang membawa kepada variasi berkelanjutan dari regangan, tegangan, perubahan volume yang dihasilkan oleh pengembangan rongga.

Pada pihak yang lain, pada antar muka elastis-plastis, semua variabel telah didefinisikan secara semestinya, yang memungkinkan tegangan radial dan keliling dan regangan dapat dihitung.Dengan menganggap posisi sebarang dari antar muka elastisplastis $\boldsymbol{b}$, daerah plastis dapat dibagi secara bertingkat (Dr). Dimulai dari $r=b$ dimungkinkan untuk menghitung $\beta$, kemudian daerah deformasi sekeliling daerah plastis dan akhirnya distribusi tegangan dalam daerah plastis. Hambatannya adalah bahwa analisa agak rumit dalam segi matematisnya, prosedur iterasi numerik yang konvergen diperlukan untuk menentukan kurva tekanan-ekspansi yang lengkap.

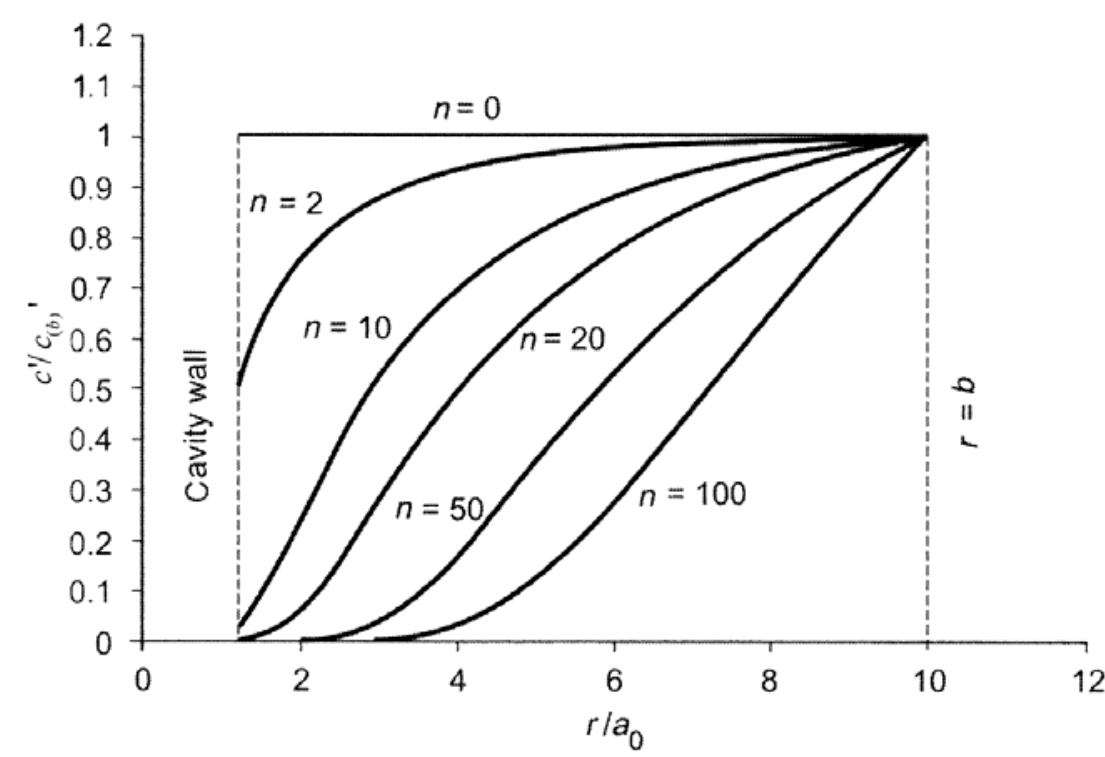

Gambar 16. Variasi dalam kohesi yang dinormalisasikan dalam daerah plastis [Schnaid \& Mantaras, 2003]. 


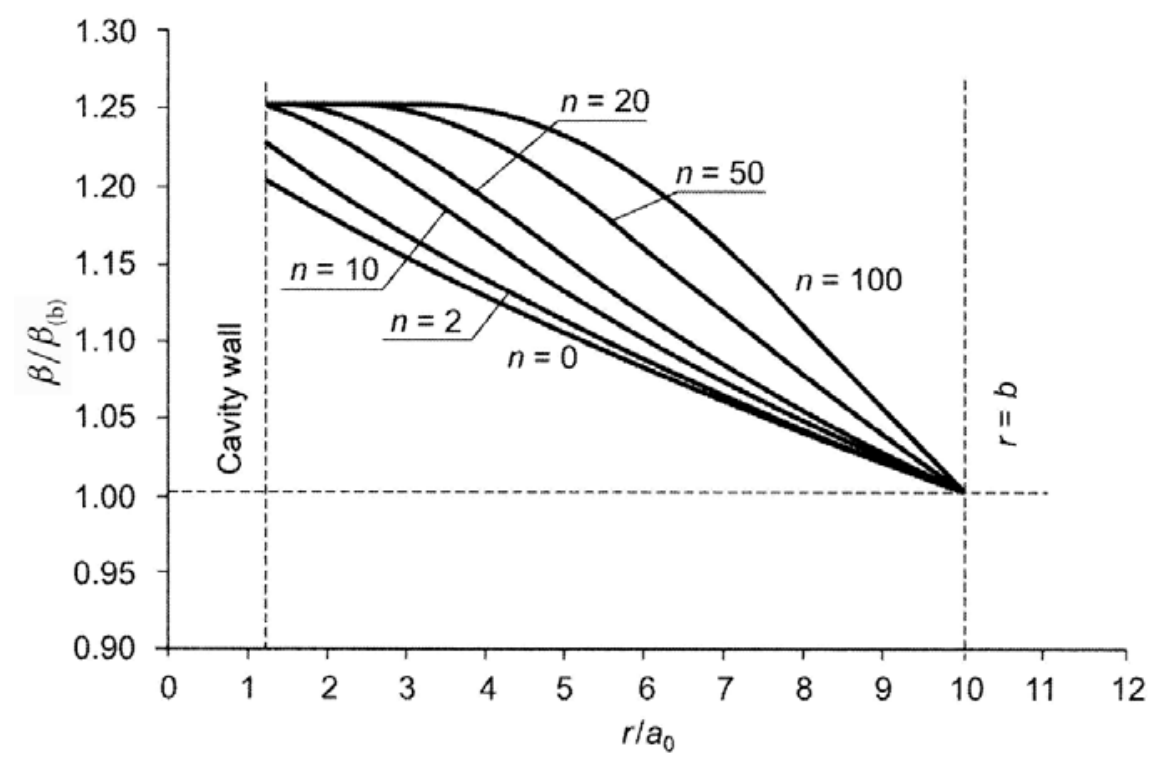

\section{Gambar 17. Dilatasi yang dinormalisasikan dalam daerah plastis sekeliling rongga yang mengembang [Schnaid \& Mantaras, 2003].}

Gambar 16 dan 17 menggambarkan fitur dari perilaku yang dinyatakan oleh rasio $\mathrm{c}^{\prime} / \mathrm{c}_{(\mathrm{b})}$ ' dan digambarkan terhadap radius rongga, dengan $\mathrm{c}_{(\mathrm{b})}$ ' dan $\beta_{(\mathrm{b})}$ menjadi kohesi intercept dan dilasi pada antar muka elastis-plastis. Variasi dalam rasio kohesi $\quad c^{\prime} / \mathbf{c}_{(b)}$ ' diperlihatkan dalam Gambar 16, dimana dimungkinkan untuk mengobservasi distribusi keseluruhan dari kohesi di sekeliling rongga dengan nilai indeks degradasi yang berbedabeda untuk suatu material yang dilatan yang mengembang sampai satu setengah kali diameter aslinya.

Titik-titik material yang terletak pada batas elastis-plastis tidak memperlihatkan degradasi struktur dan karenanya nilai kohesi yang berkenaan dengan nilai puncak maksimum, sehingga rasio $c^{\prime} / \mathbf{c}_{(b)}$ ' menjadi sama dengan satu. Sesudah pengembangan material antara dinding rongga dan batas elastis-plastis telah berubah bentuk secara plastis, dengan amplitudo regangan geser berkurang dengan bertambahnya jarak dari dinding rongga. Rasio $\mathrm{c}^{\prime} / \mathrm{c}_{(\mathrm{b})}$ ' karenanya akan berkurang dengan bertambahnya nilai $\mathrm{g}$ dan $n$, pengurangan ini menjadi sensitif untuk indeks degradasi tertentu. Gambar 17 memperlihatkan perubahan dengan radius untuk material yang sama dan kondisi batas yang diperlihatkan sebelumnya dalam Gambar 16 . Suatu material yang utuh diperlihatkan pada $\mathrm{r}=\mathrm{b}$, yang berkenaan dengan

$\beta / \beta_{(\mathrm{b})}=1$. Rasio $\beta / \beta_{(\mathrm{b})}$ bertambah secara bertahap dengan berkurangnya nilai $r$, kecepatan peningkatannya menjadi fungsi dari indeks degradasi $n$. 
Schnaid dan Mantaras (2003) mempertunjukkan hasil dari analisa numerik untuk menggambarkan pengaruh degradasi struktur pada suatu material yang berada pada keadaan kritis (critical state; $\left.\varnothing^{\prime}=\varnothing_{\mathrm{cv}}{ }^{\prime}\right)$. Kohesi intercept pada awalnya diambil $=50 \mathrm{kPa}$, yang mewakili tanah yang dibentuk. Hubungan tekanan pengembangan digambarkan dalam Gambar 18 untuk suatu rentang indeks $n$ yang berbeda-beda.

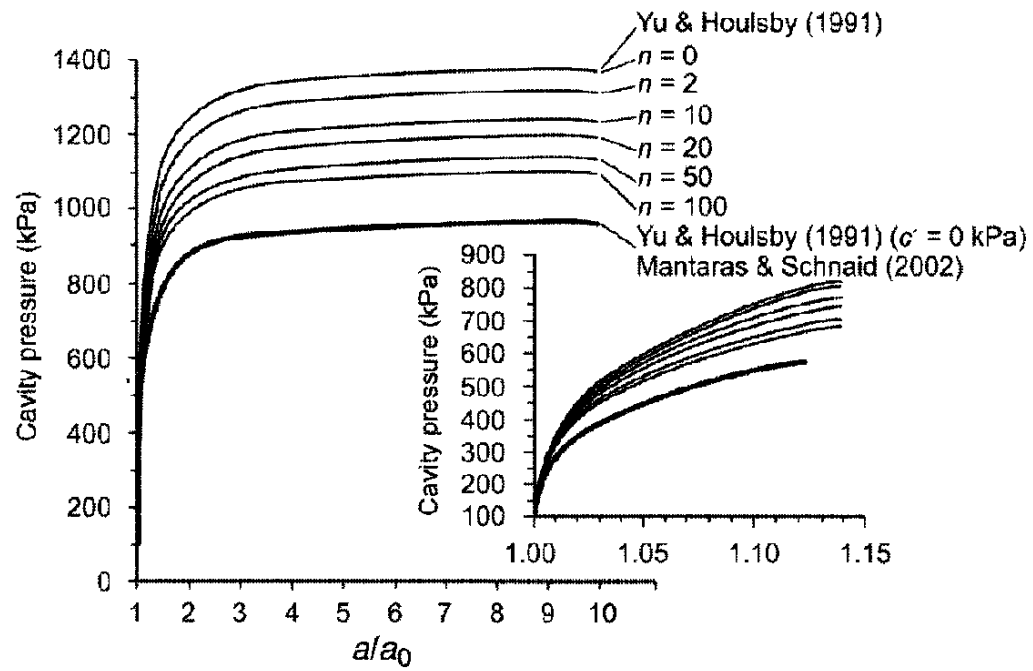

Gambar 18. Kurva hasil tekanan pengembangan dengan nilai $\mathbf{n}$ yang berbeda dengan $\varnothing^{\prime}=\varnothing_{\mathrm{cv}}$ [Schnaid \& Mantaras, 2003].

Hasil dari Yu \& Houlsby (1991) dan Mantaras \& Schnaid (2002) digambarkan juga dalam Gambar 18 untuk menjadi patokan untuk kasus dimana parameter kekuatan dipertimbangkan sebagai suatu konstanta. Perbesaran telah dibuatkan untuk awal pengembangan untuk memperlihatkan pola deformasi untuk regangan yang kecil. Dari hasil pengamatan, jelas terlihat bahwa tekanan batas (limit pressure) sangat kuat dipengaruhi oleh degradasi dari kohesi.

\section{Uji pressuremeter dalam kondisi tanah unsaturated}

Dalam interpretasi uji dilapangan, diperlukan untuk mengenal berbagai jenis material tanah, seperti tanah keras dan batuan lunak, yang mungkin tidak jenuh. Dalam kasus ini , fungsi matrix suction dan dampaknya pada permeabilitas tanah harus diketahui dan diperhitungkan sebab akan membedakan perilaku tanahnya.

Suatu sumbangan kepada analisa tanah tak jenuh adalah perluasan konsep critical state elastis-plastis oleh Alonso et al (1990). Dalam metode ini, kerangka acuan dinyatakan oleh 4 variabel : tegangan rata-rata netto $\left(p-u_{a}\right)$, selisih tegangan (deviator 
stress) $\mathrm{q}$, suction $\mathrm{s}\left(\mathrm{u}_{\mathrm{a}}-\mathrm{u}_{\mathrm{w}}\right)$ dan volume spesifik $\mathrm{v}$, dimana $\mathrm{u}_{\mathrm{a}}$ adalah tekanan udara dan $\mathrm{u}_{\mathrm{w}}$ tekanan air pori. Beberapa model konstitutif akhirnya diusulkan mengikuti konsep yang sama (misalnya Josa et al, 1992; Wheeler \& Sivakumar, 1995). Model konstitutif ini memungkinkan penurunan dari tempat kedudukan pelumeran dalam kordinat ruang $(\mathrm{p}, \mathrm{q}, \mathrm{s})$, suatu analisa yang membutuhkan 9 parameter tanah. Model parameter diperkirakan dari uji laboratorium suction-controlled seperti uji tekan isotropis dan uji kuat geser terdrainasi.

Kondisi isotropis dalam tanah tak jenuh dicirikan oleh pembebanan runtuh (loading collapse, LC) kurva pelumeran yang hukum pengerasannya (hardening law) diatur oleh deformasi volumetrik plastis total. Kurva pelumeran (yield curve) dinyatakan sebagai fungsi eksponensial negatif sebagaimana diusulkan oleh Balmaceda (1991):

$$
p_{0}=\left(p_{0}^{*}-p_{c}\right)+p_{c}\left[(1-m) e^{-\alpha s}+m\right]
$$

dimana $\mathrm{p}_{0}$ adalah tegangan prakonsolidasi pada suatu tegangan suction, $\mathrm{p}_{0}{ }^{*}$ adalah tegangan prakonsolidasidibawah kondisi terendam, $\mathrm{p}_{\mathrm{c}}$ tegangan acuan (lebih kecil dari $\mathrm{p}_{0}{ }^{*}$, tetapi mendekati harga itu), $\alpha$ faktor bentuk tak berdimensi dan $\mathrm{m}$ parameter tak berdimensi,lebih besar dari 1, yang mengontrol evolusi keruntuhan bila $\mathrm{p}_{0}$ bertambah.

Parameter keadaan yang harus dimasukkan dan diperhitungkan adalah pengaruh dari tegangan geser q. Kurva pelumeran untuk suatu contoh pada suction yang tetap s dinatakan sebagai ellips, dimana tegangan prekonsolidasi isotropis didefinisikan sebagai $\mathrm{p}_{0}$ terletak pada kurva pelumeran pembebanan runtuh Gambar 19. Garis keadaan kritis (critical state line, CSL) untuk suction yang tidak nol dianggap sebagai hasil penambahan kohesi, menjaga kemiringan M dari CSL untuk kondisi jenuh. Bila pertambahan pada kohesi mengikuti hubungan yang linier dengan suction, ellips akan berpotongan dengan sumbu $\mathrm{p}$ pada sebuah titik dimana $\mathrm{p}=-\mathrm{p}_{\mathrm{s}}=-\mathrm{k}$, dimana $\mathrm{k}$ adalah konstan. Lalu ellips dapat dinyatakan dengan persamaan dari Alonso et al, 1990):

$$
q^{2}=M^{2}\left(p+p_{s}\right)\left(p_{0}-p\right)=0
$$

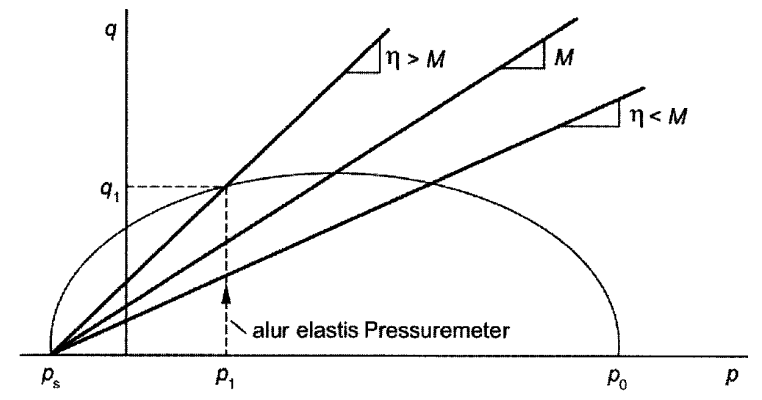

Gambar 19. Keadaan tegangan dalam ruang $p-q$ untuk alur tegangan pengembangan silinder [Schnaid, 2009]. 
Yang merupakan fungsi lumer dalam suatu model critical state modified Cam clay (Muir Wood, 1990). Dengan mengkombinasikan prinsip critical state dengan teori pengembangan rongga, Schnaid et al (2004) mengembangkan metode interpretasi yang pertama untuk menurunkan sifat uji penetrasi pressuremeter dalam tanah tak jenuh. Tegangan lumer arah radial $p$ menyatakan awal lumernya dinding rongga dalam bentuk :

$$
p=\sigma_{h 0}\left(1+\sin \phi^{\prime}\right)+c \cos \phi^{\prime}
$$

dimana $\sigma_{h 0}$ adalah tegangan horizontal dilapangan, $\phi^{\prime}$ sudut geser efektif dari tanah dan $c$ adalah kohesi total. Kondisi tanah tak jenuh membutuhkan suatu persamaan yang menghubungkan suction dengan kohesi :

$$
c=c^{\prime}+\frac{u_{a}-u_{w}}{a+b\left(u_{a}-u_{w}\right)}
$$

dimana $c^{\prime}$ adalah kohesi efektif dan $a \& b$ adalah koefisien yang best fit.

Tegangan rata-rata dinyatakan dalam tegangan oktahedral, yang dalam koordinat silinder didefinisikan oleh dua tegangan yang invarian, dinyatakan dalam koefisien tekanan tanah dalam keadaan netral,

$$
\begin{aligned}
& K_{0}=\left(\sigma_{h 0}-u_{a 0}\right) \sigma_{v}: \quad p=\frac{\sigma_{h 0}}{3}\left(2+\frac{1}{K_{0}}\right)-u_{a} \\
& q=\sigma_{h 0}\left[\frac{\left(4 K_{0}^{2}-2 K_{0}+1\right)}{K_{0}^{2}}\right]-3 \cos \phi_{p}^{\prime}\left(\frac{P_{0}^{2} \cos \phi_{p}^{\prime}-c^{2} \cos \phi_{p}^{\prime}}{P_{0}^{2}}\right)^{1 / 2}
\end{aligned}
$$

dimana $\phi_{p s}^{\prime}$ adalah sudut geser puncak dari tanah. Sehingga memungkinkan untuk menghitung tekanan lumer pada keadaan tegangan isotropis pada setiap tingkat suction yang diberikan:

$$
p_{0}=\frac{q^{2}}{M^{2}\left(p+p_{s}\right)}+p
$$

dimana $p_{s}$ dan $\mathrm{M}$ didefinisikan sebagai :

$$
\begin{aligned}
& -p_{s}=-c \cos \phi_{c s}^{\prime} \\
& M=\frac{q}{p}=\left[\frac{\left(4 K_{0}^{2}-2 K_{0}+1\right)}{K_{0}^{2}}-3 \cos ^{2} \phi_{c s}^{\prime}\right]^{1 / 2} \frac{3 K_{0}}{2 K_{0}+1}
\end{aligned}
$$

$\phi_{c s}^{\prime}$ adalah sudut geser critical state dari tanah. Perhatikan bila $K_{0}=1$, persamaan (42) menjadi : $M=\sqrt{3} \sin \phi_{c s}$. 
Dibuat anggapan bahwa suction dilapangan tetap konstan selama fase pengembangan dalam uji pressuremeter, karena besaran regangan geser hanya signifikan pada jarak radial yang sangat kecil dari dinding rongga pressuremeter (Houlsby, 1998) dan tidak ada perubahan yang penting dalam derajat kejenuhan dalam daerah yang dipengaruhi oleh pengembangan rongga. Anggapan ini membolehkan hubungan tegangan-reganganyang samadapat dipergunakan untuk analisa terdrainasi dalam tanah jenuh sebagaimana dalam tanah tak jenuh, dengan menganggap bahwa tanah tak jenuh pada suction yang tetap berperilaku secara kualitatif sebagaimana tanah dalam keadaan jenuh. Berdasarkan kerangka kerja ini, interpretasi uji pressuremeter dapat digunakan untuk menilai parameter konstitutif yang perlu untuk menjelaskan permukaan lumer tiga dimensi dalam $(\mathrm{p}, \mathrm{q}, \mathrm{s})$ ruang dalam tanah tak jenuh sebagaimana diperlihatkan dalam Gambar 20.

Pengenalan bahwa matric suction menghasilkan suatu komponen tegangan efektif tambahan menyarankan adanya kebutuhan untuk menghubungkan besarnya insitu suction dengan respon pengamatan uji dilapangan. Hal ini menyebabkan pengembangan suction monitored pressuremeter tests (SMPM), yang dapat memonitor insitu suction selama pengujian berlangsung dengan tensiometer diposisikan dekat dengan probe pressuremeter.

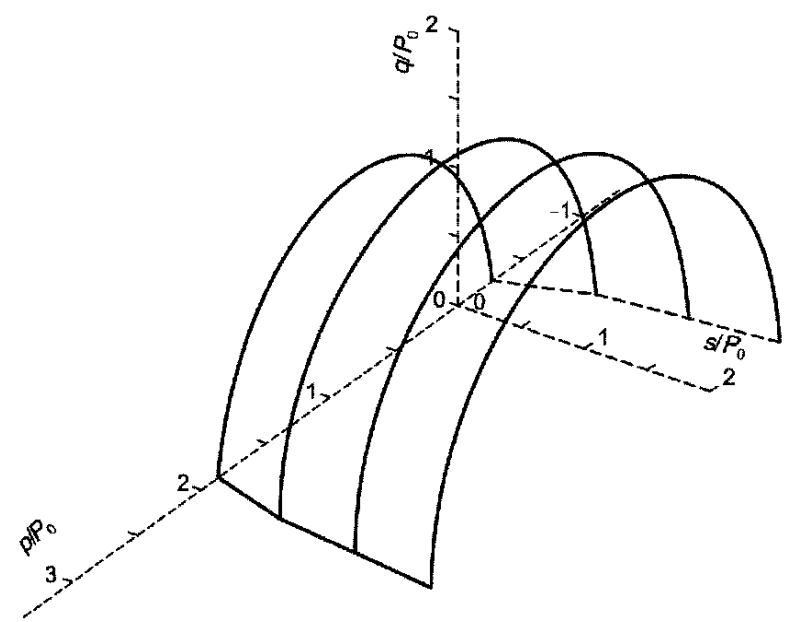

Gambar 20. Tampak tiga dimensi dari bidang pelumeran dalam ruang $\left(\mathbf{p} / \mathbf{P}_{0}, \mathbf{q} / \mathbf{P}_{0}, \mathrm{~s} / \mathbf{P}_{0}\right)$ [Schnaid, 2009]. 


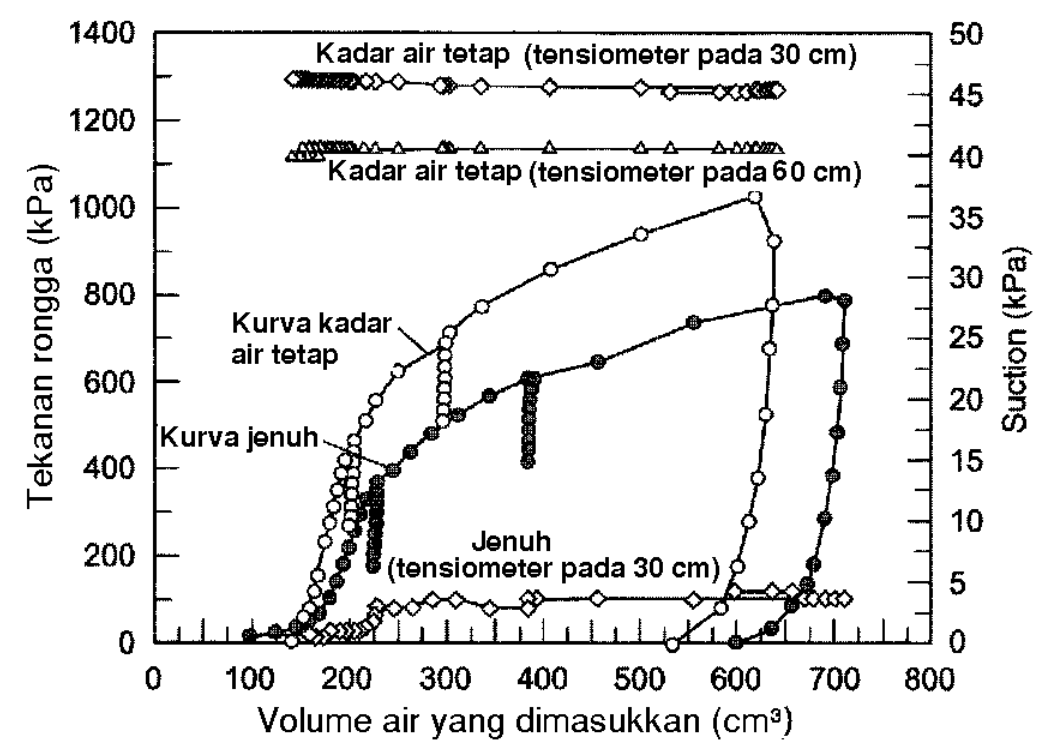

Gambar 21. Hasil uji Self Monitored Pressuremeter tests (SMPM).

\section{Kesimpulan}

1. Analisa untuk persoalan yang melibatkan pembebanan aksial simetri (axially symmetric loading) pertama kali diperkenalkan oleh Timoshenko dan Goodier (1951).

2. Pemecahan persoalan dengan menggunakan teori pengembangan rongga berbentuk silinder dengan anggapan masa tanah adalah homogen, isotropis dan medium yang menerus (continuous medium) dan regangan yang terjadi adalah kecil ( small strain).

3. Dengan teori ini dimungkinkan untuk simulasi pengembangan suatu rongga silinder yang panjang (panjang jauh lebih besar dari radius) ,baik untuk tanah lempung maupun untuk tanah butiran.

4. Material disekeliling rongga mengalami deformasi regangan membidang (plane strain), tanpa ada deformasi dalam arah sejajar dengan sumbu rongga.

5. Tegangan yang bekerja sesuai dengan definisi adalah tegangan radial, tegangan keliling dan tegangan aksial, semua tegangan adalah tegangan utama.

6. Tegangan aksial dianggap merupakan tegangan antara dan kondisi regangan membidang (plane strain) dianggap bekerja dalam arah aksial.

\section{Daftar Pustaka}

1. Alonso,E.E.,Gens,A. and Josa,A. 1990.A constitutive model for partially saturated soils. Geotechnique, 40(3):405-430 
2. ASTM D-4719 Standard test method for prebored pressuremeter testing in soils, Volume 04.08. American Society for Testing \& Materials Standard,2000

3. Carter,J.P.,Booker,J.P.and Yeung,S.K.1986.Cavity expansion in cohesive frictional soils. Geotechnique, 36:349-358

4. Haberfield,C.M.1997.Pressuremeter testing in weak rock and cemented sand.Proceedings Institution of Civil Engineers, Geotechnical Engineering ,125:168-178

5. Jeremic, B. Cavity Expansion Theory, Lecture notes Advanced Soil Mechanics, UC Davis, Fall 2008

6. Mantaras,F.M.\& Schnaid,F.2002.Cavity expansion in dilatant cohesive-frictional soils. Geotechnique, 52(5):337-348

7. Schnaid F.\& Mantaras F.M.2003.Cavity expansion in cemented materials: structure degradation effects. Geotechnique, 53(9):797-807

8. Schnaid F.2005.Geocharacterization and properties of natural soils by in-situ tests. State of the art report.Proc.16 th International Conference on Soil Mechanics \& Geotechnical Engineering (ICSMGE), Osaka, 1:3-46

9. Schnaid,F.2009.In situ Testing in Geomechanics. Taylor \& Francis, London \& New York

10. Timoshenko S.P. \& Goodier J.N. 1951. Theory of Elasticity. McGraw-Hill Book Co.,New York, NY

11. Wheeler,S.J. \& Sivakumar, V.1995. An elasto-plastic critical state framework for unsaturated soil.Geotechnique, 45(1): 35-53

12. Yu,H.S. \& Houlsby G.1991, Finite cavity expansion in dilatant soils : loading analysis. Geotechnique, 41(2):173-183 